\begin{tabular}{|c|l|}
\hline Title & $\begin{array}{l}\text { Community and trophic structures of pelagic copepods down to greater depths in the western subarctic Pacific (WEST- } \\
\text { COSMIC) }\end{array}$ \\
\hline Author(s) & $\begin{array}{l}\text { Y amaguchi, A tsushi; Watanabe, Yuji; Ishida, Hiroshi; Harimoto, Takashi; Furusawa, Kazushi; Suzuki, Shinya; } \\
\text { Ishizaka, Joji; Ikeda, T sutomu; Takahashi, Masay uki Mac }\end{array}$ \\
\hline Citation & $\begin{array}{l}\text { Deep Sea Research Part I: Oceanographic Research Papers, 49(6), 1007-1025 } \\
\text { https://doi.org/10.1016/S0967-0637(02)000080 }\end{array}$ \\
\hline Issue Date & 2002 \\
\hline Doc URL & http:/hdl.handle.net/2115/60644 \\
\hline Type & article (author version) \\
\hline File Information & Yamaguchi-2002-2.pdf \\
\hline
\end{tabular}

Instructions for use 


\section{Community and trophic structures of pelagic copepods down to the greater depths in the western subarctic Pacific (WEST-COSMIC)}

Atsushi Yamaguchia*, Yuji Watanabea, c, Hiroshi Ishida a, Takashi Harimotoa, Kazushi Furusawa $^{b}$, Shinya Suzukib, Joji Ishizakac ${ }^{c}$, Tsutomu Ikedad, Masayuki Mac Takahashie

a: Ocean Environmental Survey Team, Environmental Chemistry Department, Kansai Environmental Engineering Center Co., Ltd., 1-3-5 Azuchimachi, Chuo-ku, Osaka 541-0052, Japan.

b: Marine Biological Research Institute of Japan Co., Ltd., 4-3-16 Yutakamachi, Shinagawa-ku, Tokyo 142-0042, Japan

c: Graduate School of Marine Science and Engineering, Nagasaki University, 1-14 Bunkyo, Nagasaki 852-8521, Japan.

d: Marine Biodiversity Laboratory, Graduate School of Fisheries Science,

Hokkaido University,

3-1-1 Minato-cho, Hakodate, Hokkaido 041-0821, Japan.

e: Department of Systems Science, Graduate School of Arts and Science, University of Tokyo,

3-8-1 Komaba, Meguro-ku, Tokyo 153-8902, Japan.

* Corresponding author: (A. Yamaguchi)

Tel.: +81-6-6263-7314

Fax: +81-6-6263-7333

e-mail address: yamaguchi_atsushi@kanso.co.jp 
Abstract: As part of the research program "WEST-COSMIC (Western Pacific Environment Study on $\mathrm{CO}_{2}$ Ocean Sequestration for Mitigation of Climate Change)", vertical distribution and community structure of copepods were studied at Station Knot $\left(44^{\circ} \mathrm{N}, 155^{\circ} \mathrm{E}\right)$ down to $4000 \mathrm{~m}$ depth in the western subarctic Pacific. Vertical carbon flux mediated by copepod communities was also estimated. Both abundance and biomass of copepods were greatest in the near surface layer and decreased with increasing depth. Decrease of abundance with depth was best fitted to power regression model, while that of biomass was best described by an exponential regression model. Copepod carcasses occurred throughout the layer, and carcasses/living specimens ratios were greatest in the deepest layer (the ratio was 9.3 at 3000$4000 \mathrm{~m}$ depth). A total of 98 calanoid copepod species belonging to 38 genera and 15 families occurred in the 0-4000 m water column (Cyclopoida, Harpacticoida and Poecilostomatoida were not identified to species). The number of genera and species showed bimodal vertical distributions with peaks at 500-1000, and at 2000-3000 m both during day and night. Based on the species similarity indices, copepod community could be classified into epipelagic, mesopelagic and bathypelagic communities. Based on the feeding pattern, copepods were divided into four types: suspension feeders, suspension feeders in diapause, detritivores and carnivores. In terms of abundance, the most dominant group was suspension feeders (mainly the cyclopoid genus Oithona) in the epipelagic zone, while detritivores (mainly Poecilostomatoida genus Oncaea) were dominant in the meso- and bathypelagic zones. In terms of biomass, suspension feeders in diapause (calanoid genera Neocalanus and Eucalanus) were the major component (ca. 70\%), especially at 200-2000 m depth. Comparison of vertical flux of particulate carbon with estimated copepod ingestion/egestion rates suggests that the suspension feeding copepods receive sufficient food. For detritivorous copepods, copepod carcasses, a possible food source, are not abundant enough, so other food sources need to be considered. As a food source for carnivorous copepods, the abundance of suspension feeding and detritivorous copepods appears to be high enough to meet their demand. Our calculation showed that an average of $32 \%$ of the particulate carbon flux is consumed by copepods in the $0-4000 \mathrm{~m}$ water column.

Key words: copepods, community structure, species diversity, carbon cycle, carbon flux Regional terms: Japan, Station Knot, western subarctic Pacific Ocean 


\section{Introduction}

Copepoda is one of the important zooplankton taxa, contributing $60-80 \%$ of net zooplankton biomass in the world ocean (Longhurst, 1985). From the viewpoint of the global carbon cycle, copepods feed on organic carbon produced by tiny primary producers in the epipelagic zone, and egest large fecal pellets which sink faster than those of protists (microzooplankton), thus accelerating the biological pump (Longhurst and Harrison, 1989). Seasonal vertical migrations of large grazing copepods in the high latitude seas are regarded as an other mechanism which accelerates organic matter transfer to the deep-sea (Bradford-Grieve et al., 2001). Vinogradov (1962) hypothesized that prey-predator linkages and vertical migrations of zooplankton living at various depths in the ocean are mechanisms of rapid transportation of organic matter from the surface to deeper layers. However, this hypothesis, called the "ladder of migration", has not been evaluated quantitatively yet.

While numerous studies have been made on copepod community structure in the neritic or epipelagic zone, information about copepod communities in the oceanic meso- and bathypelagic zone is extremely limited. As one of few exceptions, Roe (1972) studied copepod community structure down to mesopelagic zone in the North Atlantic, and revealed that the number of copepods decreases exponentially with increasing depth, whereas the number of genera and species of copepods increases with increasing depth, forming a peak in the mesopelagic zone. In the North Pacific, there are no studies comparable to that of Roe.

Deep-sea studies in the western subarctic Pacific by Russian scientists have been limited to vertical distribution of zooplankton biomass (Vinogradov, 1968, 1997), features of interzonal migrating copepods in mesopelagic zones (Vinogradov and Arashkevich, 1969) and the species diversity of certain mesopelagic copepod families (Markhaseva and Razzhivin, 1992). Detailed information about entire copepod communities and its characteristics over the great depths in the North Pacific has been lacking.

Japanese scientists have studied vertical distribution patterns of copepods in the western subarctic Pacific (Furuhashi, 1966; Minoda, 1971; Morioka, 1972; Hattori, 1989, 1991), providing the list of species and abundance of each species (no biomass data were given for each species). While the occurrence of large grazing copepods Neocalanus (Calanus) cristatus which undergo an extensive ontogenetic vertical migration had been well documented in the past (Kitou, 1965; Omori, 1967; Omori and Tanaka, 1967; Sekiguchi, 1975), the life cycles of N. cristatus and other Neocalanus spp. in this region were published recently (Kobari and Ikeda, 1999, 2001a, 2001b; Tsuda et al., 1999, 2001). Also the life cycles of some mesopelagic copepods such as Paraeuchaeta elongata (Ozaki and Ikeda, 1999), Pleuromamma scutullata and Heterorhabdus tanneri (Yamaguchi and Ikeda, 2000a) and Gaidius variabilis (Yamaguchi and Ikeda, 2000b) have been evaluated successfully in the western subarctic Pacific. Despite accumulation of this new information about copepods in the western subarctic Pacific, the data needed for a quantitative evaluation of the role of copepods in the cycling of energy and matter through the entire water column are still lacking.

We aim in the present study to evaluate vertical community structures of copepods living down to $4000 \mathrm{~m}$ depth at Station Knot in the western subarctic Pacific, based on day and night samples collected in August 1998. Copepods were identified to species (calanoids only) and classified into four groups depending upon feeding characteristics, i.e. suspension feeders, suspension feeders in diapause, detritivores and carnivores. By measuring the body length of each copepod, their numbers were converted to carbon biomass. Ingestion and egestion (fecal pellet production) rates of individual copepods were calculated from their metabolic rates (oxygen consumption) using Ikeda and Motoda's (1978) approach, and the rates of the four feeding groups at various depth layers were combined with particulate carbon flux data at the same site to evaluate the interference by copepod ingestion/egestion with sinking particulate carbon through the $0-4000 \mathrm{~m}$ water column. 


\section{Materials and Methods}

Field sampling and enumeration

As part of the research program "WEST-COSMIC" ("Western Pacific Environment Assessment Study on $\mathrm{CO}_{2}$ Ocean Sequestration for Mitigation of Climate Change" cf. Harada, 1999; Ishizaka, 1999), a set of day and night deep samplings were made at Station Knot $\left(44^{\circ} \mathrm{N}\right.$, $155^{\circ} \mathrm{E}$; ca. $5340 \mathrm{~m}$ depth) located in the western subarctic Pacific from 19 to 21 August 1998 (Fig. 1). Zooplankton was collected at discrete depth intervals with closing-NORPAC nets (mesh size $90 \mu \mathrm{m}$, mouth opening $0.16 \mathrm{~m}^{2}$, cf. Motoda, 1957) from 0-100 and 100-200 m, and with VMPS (Vertical Multiple Plankton Sampler, mesh size $90 \mu \mathrm{m}$, mouth opening $1.0 \mathrm{~m}^{2}$, Tsurumi Seiki, Co. Ltd., cf. Terazaki and Tomatsu, 1997) from 200-500, 500-1000, 1000-1500, 1500-2000, 2000-3000 and 3000-4000 m. A flowmeter (Rigosha, Co. Ltd.) was mounted in the mouth of the net to register the volume of water passed through the net. Daytime samplings were made during 09:07-13:28 (local time) and night samplings during 22:06-05:02. Zooplankton samples were split on board and $1 / 2$ aliquots preserved immediately in $5 \%$ boraxbuffered formalin-seawater after the collection. Remaining $1 / 2$ aliquots were filtered with 50 $\mu \mathrm{m}$ mesh and stored at $-80^{\circ} \mathrm{C}$ for determination of total zooplankton biomass and chemical contents.

Water temperature and salinity were measured by using a CTD system (Seabird SBE9). Dissolved oxygen was determined by the Winkler titration method on water samples from 12-1 Niskin bottles (General Oceanics) rosette-mounted on the CTD system. For measuring primary production, seawater samples were collected from 6 depths between $0-100 \mathrm{~m}$ depth during 03:00-05:00 using 12-1 Niskin bottles (General Oceanics). The water samples were dispensed into four 1-1 polycarbonate bottles (one for initial and three for subsequent incubation), enriched with $\mathrm{NaH}^{13} \mathrm{CO}_{3}$ to about $10 \%$ of the total inorganic carbon, and incubated one full day in a deck incubator, through which the surface water circulated. The initial and incubated samples were filtered through precombusted Whatman GF/F filters, and the filters were frozen at $-80^{\circ} \mathrm{C}$. In the land laboratory, the isotopic ratios of ${ }^{13} \mathrm{C}$ to ${ }^{12} \mathrm{C}$ were determined following the method of Hama et al. (1983).

In the land laboratory, copepods in the zooplankton samples were identified and counted under a dissecting microscope. The samples were split with a plankton splitting device (Motoda, 1959), and $\geq 2000$ copepod specimens were enumerated in aliquots. Cyclopoida, Harpacticoida and Poecilostomatoida were identified at the order level. For Calanoida, identification was done at the species level and developmental stages whenever possible. The number of unidentified copepods was very small $(<1 \%$ of the total copepod community), and they were ignored in the following calculations. The total length (=prosome length+urosome length) of copepods were measured to the nearest $0.2 \mathrm{~mm}$ under a dissecting microscope with an eye-piece micrometer. Copepod carcasses (exoskeletons with some body tissue inside) were also identified and measured for total length.

\section{Biomass}

Dry mass biomass of each copepod was estimated from its length using the allometric equation: $\log _{10} \mathrm{DM}=2.546 \cdot \log _{10} \mathrm{TL}-6.697$, where $\mathrm{DM}$ is $\mu \mathrm{g}$ dry mass per individual and TL is total length in $\mu \mathrm{m}$ (Mizdalski, 1988). Then, dry mass biomass was converted to carbon biomass, assuming the carbon content of copepods to be $44.7 \%$ of dry mass (Båmstedt, 1986). The calculated carbon biomass data are with a factor of 0.7-1.2 nearly equal to directly determined data from the literature (Omori, 1969; Ikeda et al., 1990; Ikeda and Hirakawa, 1998). Information about the biomass of carcasses is currently limited (Wheeler, 1967; Terazaki and 
Wada, 1988). According to Terazaki and Wada (1988), dried carcasses accounted to $20 \%$ of that of living specimens for Neocalanus cristatus. Using this ratio (carcasses contain $20 \%$ DM of living specimen), dry mass of carcasses was estimated in the present study. Terazaki and Wada (1988) also reported that carbon content of N. cristatus carcasses was $51 \%$ that of dry mass, which does not differ appreciably from that (44.7\%) assumed for living specimens. Because of this, the same conversion factor (44.7\%) was used for the calculation of carbon biomass from dried biomass for both living specimens and carcasses of copepods.

Depth where population resided

To make a quantitative comparison possible, the depth above and below which $50 \%$ of the population resided ( $\mathrm{D}_{50 \%}$ ) was calculated for each copepod species (cf. Pennak, 1943). Additional calculations were made of depths above which $25 \%\left(\mathrm{D}_{25 \%}\right)$ and $75 \%\left(\mathrm{D}_{75 \%}\right)$ of the population occurred. Note that these calculations dealt with the whole populations of a given copepod species including all developmental stages.

\section{Community structure}

For calanoid copepod populations, a species diversity index (H') (Shannon and Weaver, 1949) was calculated as $\mathrm{H}^{\prime}=-\sum$ pi $\ln$ pi, where pi is the fraction of the ith ranked species in the calanoid copepod populations. Values of pi were calculated by using either the number or biomass of copepods in each sampling layer. Species similarity between samples was quantified by Mountford's (1962) similarity index (I), i.e. $I=2 c /[2 a \cdot b-(a+b) \cdot c]$, where $a$ and $b$ are the number of species in each paired samples and $\mathrm{c}$ is the number of species which occurred commonly in both samples. A matrix of similarity index between samples was generated for the subsequent cluster analysis by Mountford's method.

Carbon flux and copepod ingestion/egestion

Vertical flux of particulate carbon was estimated from the primary production data measured at the station (581 $\mathrm{mg} \mathrm{C} \mathrm{m}^{-2}$ day $^{-1}$ ), combined with the flux-primary production relationship established by Suess (1980); $\mathrm{C}_{\text {flux }}=\mathrm{C}_{\text {prod }} /(0.0238 \cdot \mathrm{z}+0.212)$, where $\mathrm{C}_{\text {prod }}$ is primary production (581 mg C m $\left.\mathrm{may}^{-1}\right)$, and $\mathrm{C}_{\text {flux }}$ is carbon flux $\left(\mathrm{mg} \mathrm{C} \mathrm{m}^{-2} \mathrm{day}^{-1}\right)$ at a given depth $(\mathrm{z}, \mathrm{m})$. The calculated particulate carbon flux in deep layer corresponds well with the values of particulate organic carbon collected by sediment traps in the same layer (e.g. Takahashi et al., 2000).

The feeding patterns of copepods (includes all orders) were classified into four types based on literature data (Arashkevich, 1969; Ohtsuka and Nishida, 1997): suspension feeders, suspension feeders in diapause, detritivores and carnivores. Detritivores in this study includes five calanoid families Diaixidae, Parkiidae, Phaennidae, Scolecitrichidae and Tharybidae and the poecilostomatoid Oncaea, all of which are considered to be adapted for feeding on detrital matter such as appendicularian houses (Ohtsuka and Nishida, 1997). Suspension feeders in diapause includes three Neocalanus species (N. cristatus, N. plumchrus, N. flemingeri) and Eucalanus bungii, which all undergo diapause at depth in the period (August) of this study (cf. Miller et al., 1984; Miller and Clemons, 1988). Since the diapause copepods cease feeding or egestion (Hallberg and Hirche, 1980; Hirche, 1989), they were omitted from the calculation of ingestion and egestion rates.

Metabolic rates (oxygen consumption, ammonia and phosphate excretion) of marine zooplankton have been expressed as a function of body mass and temperature (Ikeda, 1974). In this study, oxygen consumption rates of copepods were calculated from the observed in situ temperature and carbon biomass of each copepod using Ikeda et al's (2001) new formula for epipelagic copepods under the premise that their depth distribution does not affect the rates (cf. 
Thuesen et al., 1998), i.e., $\ln \mathrm{R}=0.124+0.780 \cdot \ln \mathrm{B}+0.073 \cdot \mathrm{T}$, where $\mathrm{R}$ is the oxygen consumption rate $\left(\mu 1 \mathrm{O}_{2}\right.$ individual $\left.^{-1} \mathrm{~h}^{-1}\right)$, $\mathrm{B}$ is the biomass of a copepod ( $\mathrm{mg} \mathrm{C}$ individual-1) and $\mathrm{T}$ is temperature $\left({ }^{\circ} \mathrm{C}\right)$. $\quad \mathrm{T}$ was represented by the integrated mean temperature of each sampling stratum. $\mathrm{R}$ was converted to carbon units assuming a respiratory quotient $\left(\left[\mathrm{CO}_{2}\right] /\left[\mathrm{O}_{2}\right]\right)$ of 0.97 (protein metabolism, cf. Gnaiger, 1983). Carbon budgets of living copepods may be expressed as: Ingestion $(I)=$ Metabolism $(M)+$ Growth $(G)+$ Egestion $(E)$. Assuming assimilation efficiency $([\mathrm{M}+\mathrm{G}] / \mathrm{I}$, or $[\mathrm{I}-\mathrm{E}] / \mathrm{I})$ and gross growth efficiency $(\mathrm{G} / \mathrm{I})$ to be $70 \%$ and $30 \%$, respectively (for detail accounts, see Ikeda and Motoda, 1978), ingestion rates (I: $\mu \mathrm{g} \mathrm{C}$ individual ${ }^{-1} \mathrm{~h}^{-1}$ ) and egestion rates (E: $\mu \mathrm{g} \mathrm{C}$ individual ${ }^{-1} \mathrm{~h}^{-1}$ ) can be calculated as $\mathrm{I}=\mathrm{M} /(0.7-0.3)$, and $\mathrm{E}=(1-0.7) \cdot \mathrm{I}$, respectively. $\mathrm{I}$ and $\mathrm{E}$ of each copepod were computed, expressed on daily basis (x 24 hours), and summed for all individuals in each depth range (mg $\mathrm{C} \mathrm{m}^{-2}$ day-1 $^{-1}$.

To quantify the role of ingestion and egestion of copepods in vertical carbon flux, a "box model" which is similar to that used by Sasaki et al. (1988) was used. Basic assumptions associated with the model were: (1) part of the particulate carbon falling through a certain depth range is intercepted and consumed by copepods inhabiting that depth range, (2) assimilation efficiency of copepods remains unchanged throughout the water column (70\%), and (3) the feces produced within a certain depth range contribute to the particulate carbon flux in the underlying layer. Our box model is different from the model by Sasaki et al. (1988) in the following points. Firstly, the depth dealt with was much greater (surface- $4000 \mathrm{~m}$ vs. surface$1000 \mathrm{~m}$ ). Secondly, the primary production rate was determined and the flux was estimated in this study, while primary production was assumed and flux was determined by Sasaki et al. (1988). Thirdly, four feeding patterns of copepods were taken into account in this study, whereas Sasaki et al. (1988) considered only dominant suspension feeders.

\section{Results}

Hydrography

The surface temperature at the sampling station was $13.5^{\circ} \mathrm{C}$ (Fig. 2). Water temperature decreased with increasing depth, and a sub-minimum of $1.9^{\circ} \mathrm{C}$ at $150 \mathrm{~m}$ and a sub-maximum of $3.3^{\circ} \mathrm{C}$ at $500 \mathrm{~m}$ were observed. The decrease of temperature with depth became less below $500 \mathrm{~m}$ and showed a minimum of $1.5^{\circ} \mathrm{C}$ at $4000 \mathrm{~m}$ depth. Integrated mean temperatures for each zooplankton sampling layer were: $5.1(0-100 \mathrm{~m}), 2.3(100-200 \mathrm{~m}), 3.2(200-500 \mathrm{~m}), 2.9$ (500-1000 m), $2.3(1000-1500 \mathrm{~m}), 2.0(1500-2000 \mathrm{~m}), 1.7(2000-3000 \mathrm{~m})$ and $1.5^{\circ} \mathrm{C}(3000-$ $4000 \mathrm{~m})$. These values were used for the calculations of ingestion and egestion rates of copepods (see "Results-Carbon budgets of copepod communities").

Salinities ranged from 32.7 to 34.7 and increased with depth, which is a common feature throughout the subarctic Pacific (Dodimead et al., 1963). General hydrographical features were similar to those of the Oyashio region (Kono, 1991): i.e. presence of subsurface minimum and maximum temperatures at depths of about $100 \mathrm{~m}$ and $300 \mathrm{~m}$, respectively, and the halocline at 200-300 $\mathrm{m}$ depth in summer.

Dissolved oxygen content was highest in the subsurface layer (maximum: $8.2 \mathrm{ml} \mathrm{l}^{-1}$ at $30 \mathrm{~m})$, decreasing rapidly with increasing depth and reaching a minimum $\left(0.46 \mathrm{ml} \mathrm{l}^{-1}\right)$ at 600 $800 \mathrm{~m}$. Dissolved oxygen lower than $2 \mathrm{ml} \mathrm{l}^{-1}$ extended to $300-2000 \mathrm{~m}$ depth. The integrated mean dissolved oxygen concentration in each zooplankton sampling layer was: 7.47 (0-100 m), 5.22 (100-200 m), 1.36 (200-500 m), 0.51 (500-1000 m), 1.18 (1000-1500 m), 1.25 (1500-2000 m), 2.47 (2000-3000 m) and 3.29 $\mathrm{ml} \mathrm{l}^{-1}(3000-4000 \mathrm{~m})$.

Numerical abundance and biomass 
Both day and night, copepods were most numerous at 0-100 m depth (3509-5082 individuals $\mathrm{m}^{-3}$ ), declined consistently downward 3000-4000 $\mathrm{m}$ depth (0.8-4.7 individuals $\mathrm{m}^{-3}$ ) (Fig. 3a). Copepod carcasses were found throughout the whole water column. Carcasses were also abundant in the surface layer (75-189 carcasses $\mathrm{m}^{-3}$ at 0-100 $\mathrm{m}$ depth), but their decrease pattern with increasing depth was less marked than that of living specimens. The minimum abundance of carcasses was 7.6-13.6 carcasses $\mathrm{m}^{-3}$ at 2000-3000 $\mathrm{m}$ (day) or 3000-4000 m (night). The ratio of carcasses to living specimens increased with increasing depth. Below $1500 \mathrm{~m}$ depth, carcasses outnumbered the living specimens, increasing to a factor of 9.3 between 3000 and $4000 \mathrm{~m}$ depth at night.

Like as its numbers, copepod carbon biomass was also greatest in the shallower layer (maximum: $20.2 \mathrm{mg} \mathrm{C} \mathrm{m}^{-3}$ at 0-100 $\mathrm{m}$ depth at night, $7.6 \mathrm{mg} \mathrm{C} \mathrm{m}^{-3}$ at 200-500 $\mathrm{m}$ depth during daytime) and decreased downward (Fig. 3b). However, the pattern of decrease with depth was different from that of numerical abundance; the pattern of $\log _{10}$ (carbon biomass) was linear with depth, which was not the case for $\log _{10}$ (abundance). The minimum biomass (0.016-0.050 $\mathrm{mg} \mathrm{C} \mathrm{m}^{-3}$ ) was at 3000-4000 m depth. In terms of carbon biomass, carcasses/living copepod ratios increased gradually toward 2000-3000 $\mathrm{m}$ depth, then increased markedly (1.1-1.2) at 3000-4000 $\mathrm{m}$ depth during day and night.

The relative composition of Calanoida, Cyclopoida, Harpacticoida and Poecilostomatoida varied greatly with depth (Fig. 4a). In terms of numerical abundance, Cyclopoida dominated in the upper $100 \mathrm{~m}(88-91 \%$ of the total). Harpacticoida occurred between 100-500 m both day and night, but their fraction was small $(<20 \%)$. Below $200 \mathrm{~m}$ depth, the proportions of the copepod orders were stable, and Calanoida $(30.4 \pm 4.7 \%$ : mean \pm 1 sd for $200-4000 \mathrm{~m}$ depth) and Poecilostomatoida $(67.1 \pm 6.5 \%)$ were the dominant taxa.

The composition the orders expressed by carbon biomass was different from that expressed by numerical abundance (Fig. 4b). This is largely because carbon biomass per individual is greatest for Calanoida. In the surface layer, Cyclopoida dominated $(49.1 \%$ at night and $70.9 \%$ during daytime of the total copepods). Their lower proportion at night was due to the ascent of large Calanoida from deeper layer. Below $200 \mathrm{~m}$ depth, the composition became stable both day and night. Calanoida ( $88.6 \pm 6.0 \%$ : mean $\pm 1 \mathrm{sd}$ for $200-4000 \mathrm{~m}$ depth) and Poecilostomatoida $(11.0 \pm 6.1 \%)$ were the two dominant copepod taxa contributing biomass in the meso- and bathypelagic zone of the subarctic Pacific ( $>99 \%$ of the total copepod biomass).

A total of 98 calanoid species belonging to 38 genera and 15 families were identified from the 0-4000 m water column (Table 1). Suspension feeders included 53 species (Note: Table 1 shows 59 species, including 4 suspension feeders in diapause and 2 non-calanoid orders). Suspension feeders in diapause were composed of four large grazing calanoids: Neocalanus cristatus, N. plumchrus, N. flemingeri and Eucalanus bungii (cf. Miller et al., 1984; Miller and Clemons, 1988). Detritivores occurred 17 species and one non-calanoid order (Poecilostomatoida), and carnivores consisted of 24 species.

The most numerous calanoid copepods were Microcalanus pygmaeus, Metridia pacifica and Paracalanus parvus, all of them were suspension feeders. In terms of carbon biomass, the most dominant species was Eucalanus bungii followed by Neocalanus cristatus and N. flemingeri. Thus the numerical dominants were not necessarily the biomass dominants. Species numerically dominant but of smaller biomass were: Microcalanus, Paracalanus and Pseudocalanus, and those numerically less dominant but larger biomass were: Eucalanus and Neocalanus. Smaller biomass of numerically dominant forms resulted from either smaller adult size or predominance of earlier copepodid stages. 
Vertical distribution

Vertical distributions of all suspension feeding species (including those in diapause) were arranged in the order from shallow to deep (Fig. 5). For suspension feeders, the depth where most of the population resided ( $\mathrm{D}_{50 \%}$ ) did not vary greatly between day and night times. It is noted that suspension feeders in diapause had broader vertical distribution ranges than those of the other suspension feeders.

$\mathrm{D}_{50 \%}$ values of some detritivores varied between day and night (Fig. 6a). Some detritivorous species (Species no. 63 and 65: Scaphocalanus subbrevicornis and Scolecithricella globulosa) showed a shallower occurrence at night, while some other species (Species no. 62, 64, 66, 68 and 74: Racovitzanus antarcticus, Scolecithricella ovata, Scaphocalanus magnus, Amallothrix inornata and Scaphocalanus affinis) showed an opposite pattern. Both day and night changes in vertical distribution were significant for each copepod (Kolmogorov-Smirnov two-sample test: $\mathrm{p}<0.05$ ). Carnivorous species tended to exhibit a stable vertical distribution pattern throughout day and night (Fig. 6b), as was seen for suspension feeders mentioned above (Fig. 5).

\section{Community structure}

The vertical distributions of the number of calanoid copepod genera and species showed bimodal peaks during day and night (Fig. 7). The shallower peak was at 500-1000 m (20 genera and 34-38 species), and the deeper peak was at 2000-3000 $\mathrm{m}$ (20 genera and 28-32 species). Species diversity index ( $\left.H^{\prime}\right)$ based on abundance or biomass showed also the same bimodal distribution pattern. The shallower peak $(500-1000 \mathrm{~m})$ of the number of genera/species coincided well with that of H' based on abundance, and the deeper peak (2000$3000 \mathrm{~m}$ ) with that of H' based on biomass.

Species similarity indices calculated for calanoid copepod populations in each sampling layer showed that: (1) the populations at near-surface layers $(0-500 \mathrm{~m})$ exhibited higher similarities, (2) below $500 \mathrm{~m}$ depth, the number of species decreased, resulting in lower similarities, and (3) copepod communities in the $0-4000 \mathrm{~m}$ depth could be classified into three groups; epipelagic $(0-200$ or $500 \mathrm{~m})$, mesopelagic $(500-1500$ or $2000 \mathrm{~m})$ and bathypelagic communities $(>2000 \mathrm{~m})$, and the boundaries between the three groups lay at 200-500 $\mathrm{m}$ and 1500-2000 m depths, respectively (Fig. 7). Day/night differences in similarity indices were observed at 0-500 $\mathrm{m}$ depth; higher similarities at night than daytime, were attributed by the nocturnal ascent of mesopelagic species to near-surface layers.

Carbon budgets of copepod communities

Numerically, suspension feeders dominated in the upper $200 \mathrm{~m}$ with $94-97 \%$ at $0-100 \mathrm{~m}$ and $72-73 \%$ at 100-200 $\mathrm{m}$ of the total copepods (Fig. 8a). Below the $200 \mathrm{~m}$, the composition stabilized and detritivores (70 $\pm 6 \%$ : mean \pm 1 sd between $200-4000 \mathrm{~m}$ ) and suspension feeders $(24 \pm 5 \%)$ became dominant groups. Throughout the whole water column, carnivores formed a small fraction (1.3 $\pm 0.8 \%)$ and suspension feeders in diapause occurred in 200-4000 m depth, were also a small component $(6.5 \pm 4.2 \%, 200-2000 \mathrm{~m}$ depth).

In terms of biomass, the composition of four feeding groups differed from that expressed by numerical abundance (Fig. 8b). Suspension feeders were abundant almost exclusively in the upper $200 \mathrm{~m}$ (of total copepods $95-98 \%$ at $0-100 \mathrm{~m}$ and $81-91 \%$ at $100-200$ $\mathrm{m})$. Below $200 \mathrm{~m}$, detritivores (14.9 $\pm 6.9 \%$ : mean $\pm 1 \mathrm{sd}$ in the $200-4000 \mathrm{~m}$ ) and carnivores $(9.9 \pm 5.5 \%)$ increased. Suspension feeders in diapause formed a large fraction at 200-2000 m $(62.8 \pm 10.3 \%)$, while their relative importance decreased below $2000 \mathrm{~m}$. The contribution of other suspension feeders increased in 2000-4000 m depth (42-44\% at 2000-3000 $\mathrm{m}$ and 52$65 \%$ at $3000-4000 \mathrm{~m}$ ).

Our calculations of ingestion/egestion rates of copepod suspension feeders, and the 
balance of particulate carbon flux (units: $\mathrm{mg} \mathrm{C} \mathrm{m}^{-2}$ day $^{-1}$ ) over the entire 0-4000 $\mathrm{m}$ water column are summarized in Fig. 9. Ingestion rates were taken into account for suspension feeders only, and egestion rates were included for all feeding groups except suspension feeders in diapause. In our preliminary calculation, ingestion rates were calculated for both suspension feeders and detritivores. Resulting total ingestion rates of the two feeding types exceeded the carbon flux below $1000 \mathrm{~m}$ depth. Considering possible utilization of particulate carbon flux by non-copepod zooplankton, copepod detritivores were omitted from our calculation of ingestion rates (food requirements of detritivores and carnivores are discussed in "Trophic structure" in Discussion section). Our results in Fig. 9 indicated that copepod suspension feeders consume $37 \%$ of carbon flux below $500 \mathrm{~m}$ depth. Throughout the entire $0-4000 \mathrm{~m}$ water column, the mean ingestion/flux ratio was $32 \pm 13 \%$ (grand mean $\pm 1 \mathrm{sd}$ ).

\section{Discussion}

Vertical distribution of standing stock

Saito et al. (1998) have reported on seasonal changes in nutrients, chlorophyll a and net zooplankton biomass in the epipelagic zone of the Oyashio region over four years. Copepoda is the most dominant taxon among net zooplankton in this region. Seasonally, net zooplankton biomass has a maximum in spring (means of four years; 37-342 $\mathrm{mg} \mathrm{C} \mathrm{m}^{-3}$ ), and a minimum in summer (8-17 $\mathrm{mg} \mathrm{C} \mathrm{m}^{-3}$ ) (Saito et al., 1998). Taking into account the present study season (August), the copepod biomass estimated in this study (7.4-20.2 $\mathrm{mg} \mathrm{C} \mathrm{m}^{-3}$ at 0 $100 \mathrm{~m}$ ) is close to Saito et al.'s data. Abundance of copepods in the epipelagic zone in the present study (3509-5082 individuals $\mathrm{m}^{-3}$ at 0-100 $\mathrm{m}$ ) is close or beyond the upper range of 83560 individuals $\mathrm{m}^{-3}$ reported by previous workers (Minoda, 1972; Hirakawa, 1981; Hattori, 1989, 1991). This can partly be explained by the smaller mesh size used in the present study $(90 \mu \mathrm{m})$ compared to that used by the previous workers $(330 \mu \mathrm{m})$. Little information is presently available for standing stocks of zooplankton in meso- and bathypelagic zones in the western subarctic Pacific.

Numerical abundance and biomass of copepods decreased rapidly with increasing depth, but their reduction patterns were different each other (Fig. 3). Two models have been proposed to express decreasing patterns of zooplankton abundance/biomass (Y) with increasing depth $(X)$. One is an exponential model $\left(\log _{10} Y=a+b \cdot X\right.$, where $a$ and $b$ are fitted constants) by Vinogradov (1968), and the other is a power model $\left(\log _{10} \mathrm{Y}=\mathrm{a}^{\prime}+\mathrm{b}^{\prime} \cdot \log _{10} \mathrm{X}\right.$, where a' and b' are fitted constants) by Koppelmann and Weikert (1992). Koppelmann and Weikert (1992) reported that the bathypelagic zooplankton biomass data fit the power model better than the exponential model. In the present study, we found that the numerical abundance data of copepods in the whole water column fit the power model and that their biomass data fit the exponential model (Table 2). With increasing depth, more pronounced reduction in the numerical abundance than in the biomass may be explained by the fact that the biomass per individual changes with depth.

\section{Copepod carcasses}

The occurrence of copepod carcasses from meso- and bathypelagic zones has been reported in the world ocean: e.g. North Atlantic (Wheeler, 1967; Roe, 1988), Indian Ocean (Geptner et al., 1990), North Pacific (Haury et al., 1995; Yamaguchi and Ikeda, 2001), Arabian Sea (BöttgerSchnack, 1996; Koppelmann et al., 2000) and Japan Sea (Terazaki and Wada, 1988). Wheeler (1967) mentioned that the species composition of the carcasses was not different from that of living specimens at the same depth, and considered that the origin of copepod carcasses is a fate of residents (they are not transported from the overlaying layer). In the present study, 
we also observed that the composition of the taxonomic order of species which produced carcasses (Fig. 10) was similar to that of living specimens in the same sampling layers (Fig. 4) (note that no Harpacticoida carcasses were found, however). In the subarctic Pacific, the large grazing copepods Neocalanus cristatus, N. plumchrus and N. flemingeri, classified as suspension feeders in diapause in this study (cf. Fig. 8), end their life cycles in the meso- and bathypelagic zones. Harding (1973) observed bacterial decomposition of organic contents of copepod carcasses, and noted that its inner tissue decomposition took 11 days in the Scotian shelf water $\left(4^{\circ} \mathrm{C}\right)$ and 3 days in the Sargasso Sea water $\left(22^{\circ} \mathrm{C}\right)$. Seki (1965) studied chitin (the major component of copepod's exoskeleton) decomposition in seawater, and noted that chitin may be mineralized in 370 days at $5^{\circ} \mathrm{C}$ and 500 days at $2^{\circ} \mathrm{C}$. Considering the habitat temperature of zooplankton in the Oyashio region $\left(<5^{\circ} \mathrm{C}\right.$ below the $40 \mathrm{~m}$ depth, cf. Fig. 2), we speculate that complete decomposition of copepod carcasses may require $>1$ year. This slow decomposition may be a cause for the abundance of carcasses in the Oyashio region.

Added to low temperature, higher abundance of copepod carcasses than of living specimens in deeper layers (Fig. 3) may possibly reflect feeding by micronektonic crustaceans and fishes which are numerous in epi- and mesopelagic zones in the Oyashio region (Nishikawa et al., 2001). In addition to these taxa, recent observations using submersibles have revealed the occurrence of potential predators on copepods such as cnidarians and ctenophores from the meso- and bathypelagic zones of the western North Pacific (Hunt and Lindsay, 1999). Copepod carcasses contain some organic matter (ca. 20\% as compared with living specimens, cf. Terazaki and Wada, 1988). Indeed, copepods have been noted as the major diet component of some dominant myctophid fishes such as Diaphus theta, Stenobrachius leucopsarus and S. nannochir (Moku et al., 2000), although the separation of its carcasses from living specimens from the stomach of these fishes has not been attempted. Not only as a potential food source, copepod carcasses may also be important as a site of bacterial growth to form deep-sea detritus (Harding, 1973).

\section{Community structure}

Our analysis of copepod communities in the 0-4000 m water column of the subarctic Pacific revealed that (1) both genus and species exhibited bimodal vertical distributions, at 500-1000 $\mathrm{m}$ and 2000-3000 $\mathrm{m}$ depth, and the number of genera and species composed of the shallow peak were slightly greater than those of the deep peak (Fig. 7), (2) species diversity indices indicated that the community structures of the peaks were different; biomass-dominant species formed the shallow peak while numerical-dominant species constituted the deep peak, and (3) similarity indices showed that the copepod communities could be divided into epipelagic, mesopelagic and bathypelagic communities, and their boundaries were at 200-500 m and 1500$2000 \mathrm{~m}$ depth, respectively. These vertical features of copepod communities at Station Knot are comparable to those being reported from the North Atlantic (Roe, 1972; Deevey and Brooks, 1977), Red Sea (Weikert, 1982), Arabian Sea (Böttger-Schnack, 1996), Mediterranean Sea (Weikert and Trinkaus, 1990) and Greenland Sea (Richter, 1994). Among these studies, Böttger-Schnack (1996) noted that Poecilostomatoida (mainly Oncaea) contributed $60-80 \%$ of total copepods in the meso- and bathypelagic zone of the Arabian Sea. Poecilostomatoida also dominated in abundance of the total copepods in the meso- and bathypelagic zone of Station Knot (ca. 70\%, cf. Fig. 4a), thereby consistent with the finding of Böttger-Schnack (1996), despite the fact that hydrographic conditions (temperature, salinity and dissolved oxygen) between Station Knot ( $44^{\circ} \mathrm{N}$ in the subarctic Pacific) and Böttger-Schnack's (1996) study site $\left(15-20^{\circ} \mathrm{N}\right.$ in the Arabian Sea) are very different. While predominance of Poecilostomatoida in the meso- and bathypelagic zones has not been noted in the results of other studies mentioned above, it is probable that Poecilostomatoida (body length; $<1.0 \mathrm{~mm}$ ) could not be collected effectively in their samplings with larger mesh nets $(>200 \mu \mathrm{m})$. The 
mesh sizes of nets used by Böttger-Schnack (1996) and us were 55 and $90 \mu \mathrm{m}$, respectively.

Vertical structures of copepod species diversity have been studied in the North Atlantic (Roe, 1972, 1984), Sargasso Sea (Deevey and Brooks, 1977), Mediterranean Sea (Scotto di Carlo et al., 1984), Greenland Sea (Richter, 1994) and Arctic Ocean (Kosobokova and Hirche, 2000). As a common feature of these studies, the number of genera and species increased with increasing depth, as was seen in the present study. However, the depth where the peak of the number of species occurred is different, ranging from 50-200 $\mathrm{m}$ in Mediterranean Sea (Scotto di Carlo et al., 1984) to 1000-1500 $\mathrm{m}$ in the Greenland Sea (Richter, 1994). Bimodal peaks of the number of genera and species found in the present study has not been reported previously. The bimodal distribution pattern was observed both day and night (Fig. 7). Considering the depth range studied by previous workers (maximum: 600-3000 m), as compared with $4000 \mathrm{~m}$ in our study, possible overlooking of the bimodal pattern by previous workers cannot be ruled out.

Information about the similarities of community structures of copepods living in the 0 $4000 \mathrm{~m}$ water column is extremely limited. Richter (1994) conducted year-round observations on copepod communities down to $3000 \mathrm{~m}$ in the Greenland Sea and noted that the epipelagic $(0-300 \mathrm{~m})$ and mesopelagic communities $(300-1000 \mathrm{~m})$ were very similar, while the bathypelagic community $(1000-3000 \mathrm{~m})$ was different and exhibited extremely low similarities to the epi-/mesopelagic communities, as was observed at Station Knot in the subarctic Pacific in the present study (Fig. 7). The boundary between epi-/mesopelagic communities and bathypelagic community is at $1000 \mathrm{~m}$ depth in the Greenland Sea (Richter, 1994), and at 1500-2000 m depth in the subarctic Pacific (Fig. 7).

Trophic structure

Our calculations of ingestion and egestion rates of copepods living at various depth strata based on oxygen consumption data given by Ikeda et al. (2001), may be underestimates because Ikeda et al.'s experiments were on specimens incubated in filtered seawater (no food). As an other source of possible error, assimilation efficiency of copepods, assumed as $70 \%$ in our calculation, could vary depending on food types (Conover, 1966), but there are no available data on deep-living copepods feeding on natural food particles. Feeding patterns of copepods were divided into four types, and the sinking particulate carbon was assumed to be utilized by suspension feeders only. It is concluded that suspension feeders could satisfy their food requirements by using sinking particulate carbon (Fig. 9), which agrees with Sasaki et al.'s (1988) conclusion.

As a source of detritus, copepod carcasses were quantified in the present study. However, the comparison between ingestion rates of detritivores and copepod carcasses showed that carcasses are used up by detritivores within 1.0-62.0 days (9.4 \pm 15.3 days, mean \pm 1 sd of water column) (Table 3 ). While there are no data on the production rates of copepod carcasses available, our calculation suggest that the carcasses may not be sufficient as a food source of detritivores and other food sources such as appendicularian houses need to be considered. Appendicularian houses are known to be an important source of detritus (Alldredge, 1976). However, because of their large size and the low density of appendicularian houses, it is difficult to quantify them by water samplings. By net sampling, appendicularian houses may be caught, but they will break down during the net towing process because of its fragile nature. Based on direct observations and sampling by using submersibles in the mesopelagic zone of Monterey Bay, Steinberg et al. (1994) reported that the density of zooplankton associated with detritus (giant larvacean houses) was one order of magnitude greater than that in the nearby water column. According to Steinberg et al. (1994), most $(96 \%)$ of the zooplankton associated with detritus are detritivorous copepods (Scolecitrichidae and Oncaeidae). Detritivorous copepods utilize floating detritus not only 
for feeding but also as a living habitat during juvenile stages (Ferrari and Steinberg, 1993), implying that pelagic detritus has a function of semi-enclosed microcosm in the water column. In the present study, most copepods have species-specific vertical distribution ranges, while only detritivorous species showed substantial day and night differences in their vertical distribution patterns (Table 4). The broader and uneven vertical distribution patterns of detritivores may be caused by their association with detritus, which is distributed unevenly in the water column (Alldredge, 1976).

As food for carnivorous copepods, suspension feeding and detritivorous copepods are assumed. Suspension feeders in diapause (Neocalanus spp. and Eucalanus bungii) are considered too large to eaten by carnivorous copepods. Suspension feeders in diapause in deep layer are known to be utilized by mesopelagic micronektonic fishes (Stenobrachius nannochir) in the western subarctic Pacific (Moku et al., 2000). Comparing carnivores' ingestion rates with the total abundance of suspension feeders (excepting those in diapause) and detritivores, our calculation indicated that carnivores feed up them in 49-688 days ( $179 \pm 211$ days, mean \pm 1 sd of water column) (Table 5). While no production data for these non-carnivorous copepods are presently available, this calculation implies that carnivorous copepods in each depth layer may be satisfying their food demand by eating the noncarnivorous copepods.

Particulate carbon fluxes are utilized by meso- and bathypelagic copepods as "falling rain" (Vinogradov, 1968). The important suspension feeders in the mesopelagic zone of the subarctic Pacific are Gaidius variabilis, Pleuromamma scutullata and Gaetanus simplex (Species no. 13, 14 and 15 in Table 1, vertical distributions are 250-1000 m, cf. Fig. 5). They are considered to feed mainly on particulate carbon fluxes such as dead phytoplankton cells and fecal pellets falling from the upper layers. These species are known to reproduce throughout the year, adjusting their main reproduction events to phytoplankton bloom season (Yamaguchi and Ikeda, 2000a, b). In other words, the magnitude of particulate carbon flux is a main factor controlling their reproductive success. In the present calculation, suspension feeders consume $32 \%$ on average of the particles throughout $0-4000 \mathrm{~m}$ depth stratum (Fig. 9), which is close to $38 \%$ reported for copepod populations off Sanriku in the western subarctic Pacific by Sasaki et al. (1988) although Sasaki et al.'s calculations dealt with 0-1000 m depth only.

\section{Acknowledgements}

WEST-COSMIC (Western Pacific Environment Assessment Study on $\mathrm{CO}_{2}$ Ocean

Sequestration for Mitigation of Climate Change) was supported by New Energy Industry Development Organization (NEDO). We gratefully acknowledge the officers and crews of R.V. Hakurei-Maru no. 2 and colleagues of Kansai Environmental Engineering Center for their kind help in field sampling. We thank M. Toyota and Y. Sekido of the Marine Biological Research Institute of Japan for their cooperation during the field sampling and identification and enumeration of the plankton samples. We also thank three anonymous reviewers for helpful comments on the manuscript. 


\section{References}

Alldredge, A.L., 1976. Discarded appendicularian houses as sources of food, surface habitats, and particulate organic matter in planktonic environments. Limnology and Oceanography 21, 14-23.

Arashkevich, Ye.G., 1969. The food and feeding of copepods in the northwestern Pacific. Oceanology 9, 695-709.

Båmstedt, U., 1986. Chemical composition and energy content. In: Corner, E.D.S., O'Hara, S.C.M. (Eds.), The Biological Chemistry of Marine Copepods. Clarendon Press, Oxford, pp. 1-58.

Böttger-Schnack, R., 1996. Vertical structure of small metazoan plankton, especially noncalanoid copepods. I. Deep Arabian Sea. Journal of Plankton Research 18, 1073-1101.

Bradford-Grieve, J.M., Nodder, S.D., Jillett, J.B., Currie, K., Lassey, K.R., 2001. Potential contribution that the copepod Neocalanus tonsus makes to downward carbon flux in the Southern Ocean. Journal of Plankton Research 23, 963-975.

Conover, R.J., 1966. Factors affecting the assimilation of organic matter by zooplankton and the question of superfluous feeding. Limnology and Oceanography 11, 346-354.

Deevey, G.B., Brooks, A.L., 1977. Copepods of the Sargasso Sea off Bermuda: species composition, and vertical and seasonal distribution between the surface and $2000 \mathrm{~m}$. Bulletin of Marine Science 27, 256-291.

Dodimead, A.J., Favorite, F., Hirano, T., 1963. Review of oceanography of the subarctic Pacific region. Bulletin of the International North Pacific Fisheries Commission 13, 1-195.

Ferrari, F.D., Steinberg, D.K., 1993. Scopalatum vorax (Esterly, 1911) and Scolecithricella lobophora Park, 1970, calanoid copepods (Scolecitrichidae) associated with a pelagic tunicate in Monterey Bay. Proceedings of the Biological Society of Washington 106, 467-489.

Furuhashi, K., 1966. Studies on the vertical distribution of copepods in the Oyashio region east of Japan and in the Kuroshio region south of Japan. Publications of the Seto Marine Biological Laboratory 14, 295-322.

Geptner, M.V., Zaikin, A.N., Rudyakov, Yu.A., 1990. Dead copepods in plankton: Facts and hypotheses. Oceanology 30, 99-102.

Gnaiger, E., 1983. Calculation of energetic and biochemical equivalents of respiratory oxygen consumption. In: Gnaiger, E., Forstner, H. (Eds.), Polarographic oxygen sensors. Springer-Verlag, Berlin, pp. 337-345.

Hallberg, E., Hirche, H.-J., 1980. Differentiation of mid-gut in adults and over-wintering copepodids of Calanus finmarchicus (Gunnerous) and C. helgolandicus Claus. Journal of Experimental Marine Biology and Ecology 48, 283-295.

Hama, T., Miyazaki, T., Ogawa, Y., Iwakuma, T., Takahashi, M., Otsuki, A., Ichimura, S., 1983. Measurement of photosynthetic production of a marine phytoplankton population using a stable ${ }^{13} \mathrm{C}$ isotope. Marine Biology 73, 31-36.

Harada, K., 1999. Oceanic environment of the western North Pacific for the $\mathrm{CO}_{2}$ sequestration. In: Mitsukawa, H. (Ed.), Proceedings of the 2nd international symposium on ocean sequestration of carbon dioxide. New Energy and Industrial Technology Development Organization, Tokyo, pp. 15-19.

Harding, G.C.H., 1973. Decomposition of marine copepods. Limnology and Oceanography 18, 670-673.

Hattori, H., 1989. Bimodal vertical distribution and diel migration of the copepods Metridia pacifica, M. okhotensis and Pleuromamma scutullata in the western North Pacific Ocean. Marine Biology 103, 39-50.

Hattori, H., 1991. Vertical distribution of zooplankton in the warm core off Sanriku (86B) 
and adjacent Oyashio water, with special reference to copepods record (in Japanese with English abstract). Bulletin of the Hokkaido National Fisheries Research Institute 55, 59-67.

Haury, L., Fey, C., Gal, G., Hobday, A., Genin, A., 1995. Copepod carcasses in the ocean. I. Over seamounts. Marine Ecology Progress Series 123, 57-63.

Hirakawa, K., 1981. Population structures of cold water copepods off the southeastern coast of Hokkaido in winter and spring (in Japanese with English abstract). Research Institute of North Pacific Fisheries Hokkaido University (Special volume), 37-44.

Hirche, H.-J., 1989. Spatial distribution of digestive enzyme activities of Calanus finmarchicus and Calanus hyperboreus in Fram Strait/Greenland Sea. Journal of Plankton Research 11, 431-443.

Hunt, J.C., Lindsay, D.L., 1999. Methodology for creating an observational database of midwater fauna using submersibles: Results from Sagami Bay, Japan. Plankton Biology and Ecology 46, 75-87.

Ikeda, T., 1974. Nutritional ecology of marine zooplankton. Memoirs of Faculty of Fisheries Hokkaido University 22, 1-97.

Ikeda, T., Hirakawa, K., 1998. Metabolism and body composition of zooplankton in the cold mesopelagic zone of the southern Japan Sea. Plankton Biology and Ecology 45, 3144.

Ikeda, T., Motoda, S., 1978. Estimated zooplankton production and their ammonia excretion in the Kuroshio and adjacent seas. Fisheries Bulletin 76, 357-367.

Ikeda, T., Hirakawa, K., Kajihara, N., 1990. Some characteristics of a coldwater copepod Calanus cristatus from regions of the Japan Sea covered by the Tsushima warm current. Bulletin of the Japan Sea National Fisheries Research Institute 40, 51-65.

Ikeda, T., Kanno, Y., Ozaki, K., Shinada, A., 2001. Metabolic rates of epipelagic marine copepods as a function of body mass and temperature. Marine Biology 139, 587-596.

Ishizaka, J., 1999. Biological impacts: structure of marine ecosystem and impact assessment. In: Mitsukawa, H. (Ed.), Proceedings of the 2nd international symposium on ocean sequestration of carbon dioxide. New Energy and Industrial Technology Development Organization, Tokyo, pp. 8-14.

Kitou, M., 1965. The distribution of the four boreal species of copepoda in the western North Pacific. Oceanographical Magazine 17, 95-107.

Kobari, T., Ikeda, T., 1999. Vertical distribution, population structure and life cycle of Neocalanus cristatus (Crustacea: Copepoda) in the Oyashio region, with notes on its regional variations. Marine Biology 134, 683-696.

Kobari, T., Ikeda, T., 2001a. Life cycle of Neocalanus flemingeri (Crustacea: Copepoda) in the Oyashio region, western subarctic Pacific, with notes on its regional variations. Marine Ecology Progress Series 209, 243-255.

Kobari, T., Ikeda, T., 2001b. Ontogenetic vertical migration and life cycle of Neocalanus plumchrus (Crustacea: Copepoda) in the Oyashio region, with notes on regional variations in body sizes. Journal of Plankton Research 23, 287-302.

Kono, T., 1991. Water masses and water systems in the North Pacific western subarctic region (in Japanese with English abstract). Bulletin of the Hokkaido National Fisheries Research Institute 55, 91-108.

Koppelmann, R., Weikert, H., 1992. Full-depth zooplankton profiles over the deep bathyal of the NE Atlantic. Marine Ecology Progress Series 86, 263-272.

Koppelmann, R., Schäfer, P., Schiebel, R., 2000. Organic carbon losses measured by heterotrophic activity of mesozooplankton and $\mathrm{CaCO}_{3}$ flux in the bathypelagic zone of the Arabian Sea. Deep-Sea Research II 47, 169-187.

Kosobokova, K., Hirche, H.-J., 2000. Zooplankton distribution across the Lomonosov Ridge, 
Arctic Ocean: Species inventory, biomass and vertical structure. Deep-Sea Research I 47, 2029-2060.

Longhurst, A.R., 1985. The structure and evolution of plankton communities. Progress in Oceanography $15,1-35$.

Longhurst, A.R., Harrison, W.G., 1989. The biological pump: Profiles of plankton production and consumption in the open ocean. Progress in Oceanography 22, 47123.

Markhaseva, Ye.L., Razzhivin, V.Yu., 1992. Vertical distribution of copepods of the family Aetideidae (Copepoda, Calanoida) in the Vicinity of the Kurile-Kamchatka Trench. Oceanology 32, 611-617.

Miller, C.B., Clemons, M.J., 1988. Revised life history analysis for large grazing copepods in the subarctic Pacific Ocean. Progress in Oceanography 20, 293-313.

Miller, C.B., Frost, B.W., Batchelder, H.P., Clemons, M.J., Conway, R.E., $1984 . \quad$ Life histories of large, grazing copepods in a subarctic ocean gyre: Neocalanus plumchrus, Neocalanus cristatus, and Eucalanus bungii in the northeast Pacific. Progress in Oceanography 13, 201-243.

Minoda, T., 1971. Pelagic copepoda in the Bering Sea and the northwestern North Pacific with special reference to their vertical distribution. Memoirs of Faculty of Fisheries Hokkaido University 18, 1-74.

Minoda, T., 1972. Characteristics of the vertical distribution of copepods in the Bering Sea and south of Aleutian Chain, May-June, 1962. In: Takenouchi, A.Y., Anraku, M., Banse, K., Kawamura, T., Nishizawa, S., Parsons, T.R., Tsujita, T. (Eds.), Biological Oceanography of the Northern North Pacific Ocean. Idemitsu Shoten, Tokyo, pp. 323-331.

Mizdalski, E., 1988. Weight and length data of zooplankton in the Weddell Sea in austral spring 1986 (Ant V/3). Berichte zur Polarforschung 55, 1-72.

Moku, M., Kawaguchi, K., Watanabe, H., Ohno, A., 2000. Feeding habits of three dominant myctophid fishes, Diaphus theta, Stenobrachius leucopsarus and S. nannochir, in the subarctic and transitional waters of the western North Pacific. Marine Ecology Progress Series 207, 129-140.

Morioka, Y., 1972. The vertical distribution of calanoid copepods off the southeast coast of Hokkaido. In: Takenouchi, A.Y., Anraku, M., Banse, K., Kawamura, T., Nishizawa, S., Parsons, T.R., Tsujita, T. (Eds.), Biological Oceanography of the Northern North Pacific Ocean. Idemitsu Shoten, Tokyo, pp. 309-321.

Motoda, S., 1957. North Pacific standard plankton net (in Japanese with English abstract). Information Bulletin on Planktology in Japan 4, 13-15.

Motoda, S., 1959. Devices of simple plankton apparatus. Memoirs of Faculty of Fisheries Hokkaido University 7, 73-94.

Mountford, M.D., 1962. An index of similarity and its application to classificatory problems. In: Murphy, P.W. (Ed.), Progress in Soil Science. Butterworths, Kent, pp. 43-50.

Nishikawa, J., Nishida, S., Moku, M., Hidaka, K., Kawaguchi, K., 2001. Biomass, abundance, and vertical distribution of micronekton and large gelatinous zooplankton in the subarctic Pacific and the Bering Sea during the summer of 1997 . Journal of Oceanography 57, 361-375.

Ohtsuka, S., Nishida, S., 1997. Reconsideration on feeding habits of marine pelagic copepods (Crustacea) (in Japanese with English abstract). Oceanography in Japan 6, 299-320.

Omori, M., 1967. Calanus cristatus and submergence of the Oyashio water. Deep-Sea Research 14, 525-532.

Omori, M., 1969. Weight and chemical composition of some important oceanic zooplankton in the North Pacific Ocean. Marine Biology 3, 4-10. 
Omori, M., Tanaka, O., 1967. Distribution of some cold-water species of copepods in the Pacific water off east-central Honshu, Japan. Journal of the Oceanographical Society of Japan 23, 7-17.

Ozaki, K., Ikeda, T., 1999. Vertical distribution, population structure and life cycle of the mesopelagic copepod Paraeuchaeta elongata off Cape Esan, southwestern Hokkaido, Japan. Plankton Biology and Ecology 46, 48-53.

Pennak, R.W., 1943. An effective method of diagramming diurnal movements of zooplankton organisms. Ecology 24, 405-407.

Richter, C., 1994. Regional and seasonal variability in the vertical distribution of mesozooplankton in the Greenland Sea. Berichte zur Polarforschung 154, 1-87.

Roe, H.S.J., 1972. The vertical distributions and diurnal migrations of calanoid copepods collected on the SOND cruise, 1965. I. The total population and general discussion. Journal of the Marine Biological Association of the United Kingdom 52, 277-314.

Roe, H.S.J., 1984. The diel migrations and distributions within mesopelagic community in the north east Atlantic. 4. The copepods. Progress in Oceanography 13, 353-388.

Roe, H.S.J., 1988. Midwater biomass profiles over the Madeira Abyssal Plain and the contribution of copepods. Hydrobiologia 167/168, 169-181.

Saito, H., Kasai, H., Kashiwai, M., Kawasaki, Y., Kono, T., Taguchi, S., Tsuda, A., 1998. General description of seasonal variations of nutrients, chlorophyll-a, and netplankton biomass along the A-line transect, western subarctic Pacific, from 1990-1994. Bulletin of the Hokkaido National Fisheries Research Institute 62, 1-62.

Sasaki, H., Hattori, H., Nishizawa, S., 1988. Downward flux of particulate organic matter and vertical distribution of calanoid copepods in the Oyashio Water in summer. DeepSea Research 35, 505-515.

Scotto di Carlo, B., Ianora, A., Fresi, E., Hure, J., 1984. Vertical zonation patterns for Mediterranean copepods from the surface to $3000 \mathrm{~m}$ at a fixed station in the Tyrrhenian Sea. Journal of Plankton Research 6, 1031-1056.

Seki, H., 1965. Microbiological studies on the decomposition of chitin in marine environment-IX. Rough estimation on chitin decomposition in the ocean. Journal of the Oceanographical Society of Japan 21, 253-260.

Sekiguchi, H., 1975. Distributional expansion of the pelagic copepod in relation to its largescale ontogenetic vertical migration. Bulletin of the Faculty of Fisheries Mie University 2, 19-28.

Shannon, C.E., Weaver, W., 1949. The Mathematical Theory of Communication. University of Illinois Press, Champaign.

Steinberg, D.K., Silver, M.W., Pilskaln, C.H., Coale, S.L., Paduan, J.B., 1994. Midwater zooplankton communities on pelagic detritus (giant larvacean houses) in Monterey Bay, California. Limnology and Oceanography 39, 1606-1620.

Suess, E., 1980. Particulate organic carbon flux in the oceans- surface productivity and oxygen utilization. Nature 288, 260-263.

Takahashi, K., Fujitani, N., Yanada, M., Maita, Y., 2000. Long-term biogenic particle fluxes in the Bering Sea and the central subarctic Pacific Ocean, 1990-1995. Deep-Sea Research I 47, 1723-1759.

Terazaki, M., Tomatsu, C., 1997. A vertical multiple opening and closing plankton sampler. Journal of Advanced Marine Science Technological Society 3, 127-132.

Terazaki, M., Wada, M., 1988. Occurrence of large numbers of carcasses of the large, grazing copepod Calanus cristatus from the Japan Sea. Marine Biology 97, 177-183.

Thuesen, E.V., Miller, C.B., Childress, J.J., 1998. Ecophysiological interpretation of oxygen consumption rates and enzymatic activities of deep-sea copepods. Marine Ecology Progress Series 168, 95-107. 
Tsuda, A., Saito, H., Kasai, H., 1999. Life histories of Neocalanus flemingeri and Neocalanus plumchrus (Calanoida: Copepoda) in the western subarctic Pacific. Marine Biology $135,533-544$.

Tsuda, A., Saito, H., Kasai, H., 2001. Life history strategies of subarctic copepods Neocalanus flemingeri and N. plumchrus, especially concerning lipid accumulation patterns. Plankton Biology and Ecology 48, 52-58.

Vinogradov, M.E., 1962. Feeding of the deep-sea zooplankton. Rapports et ProcèsVerbaux des Réunions Conseil International pour l'Exploration de la Mer 153, 114-120.

Vinogradov, M.E., 1968. Vertical Distribution of the Oceanic Zooplankton. Academy of Science of the U.S.S.R., Institut of Oceanography. (in Russian, translated by Israel Program for Scientific Translations) Keter Press, Jerusalem 1970.

Vinogradov, M.E., 1997. Some problems of vertical distribution of meso- and macroplankton in the Ocean. Advances in Marine Biology 32, 1-92.

Vinogradov, M.Ye., Arashkevich, Ye.G., 1969. Vertical distribution of interzonal copepod filter feeders and their role in communities at different depths in the north-western Pacific. Oceanology 9, 399-409.

Weikert, H., 1982. The vertical distribution of zooplankton in relation to habitat zones in the area of the Atlantis II Deep, central Red Sea. Marine Ecology Progress Series 8, 129143.

Weikert, H., Trinkaus, S., 1990. Vertical mesozooplankton abundance and distribution in the deep eastern Mediterranean Sea SE of Crete. Journal of Plankton Research 12, 601628.

Wheeler, E.H., 1967. Copepod detritus in the deep sea. Limnology and Oceanography 12, 697-702.

Yamaguchi, A., Ikeda, T., 2000a. Vertical distribution, life cycle, and body allometry of two oceanic calanoid copepods (Pleuromamma scutullata and Heterorhabdus tanneri) in the Oyashio region, western North Pacific Ocean. Journal of Plankton Research 22, 29 46.

Yamaguchi, A., Ikeda, T., 2000b. Vertical distribution, life cycle and developmental characteristics of mesopelagic calanoid copepod Gaidius variabilis (Aetideidae) in the Oyashio region, western North Pacific Ocean. Marine Biology 137, 99-109.

Yamaguchi, A., Ikeda, T., 2001. Abundance and population structure of three mesopelagic Paraeuchaeta species (Copepoda: Calanoida) in the Oyashio region, western subarctic Pacific Ocean with notes on their carcasses and epizoic ciliates. Plankton Biology and Ecology 48, 104-113. 


\section{Figure Captions}

Fig. 1. Location of Station Knot $\left(44^{\circ} \mathrm{N}, 155^{\circ} \mathrm{E}\right)$ in the western subarctic Pacific Ocean. For comparison, locations of Station Papa (cf. Miller et al., 1984) in the eastern subarctic Pacific and Site H (cf. Kobari and Ikeda, 1999) in the western subarctic Pacific are superimposed.

Fig. 2. Vertical distributions of temperature $\left({ }^{\circ} \mathrm{C}\right)$, salinity and dissolved oxygen $\left(\mathrm{ml} \mathrm{l}^{-1}\right)$ at Station Knot in the western subarctic Pacific Ocean, 19-21 August 1998.

Fig. 3. Vertical distributions, on log scales, of abundance (a) and biomass (b) of copepods at Station Knot in the western subarctic Pacific Ocean. Squares denote ratio of carcasses to living specimens, and 1.0 values (carcasses equal to living specimens) are shown (dotted vertical lines).

Fig. 4. Vertical changes in the composition of four orders (Calanoida, Cyclopoida, Harpacticoida and Poecilostomatoida) of copepods at Station Knot in the western subarctic Pacific Ocean in terms of abundance (a) and biomass (b).

Fig. 5. Vertical distribution of suspension feeding copepods at Station Knot in the western subarctic Pacific Ocean. Of each species, open and solid symbols indicate 50\% distribution depth ( $\left.\mathrm{D}_{50 \%}\right)$ at day and night, respectively. Vertical bars indicate depth ranges where $25 \%\left(\mathrm{D}_{25 \%}\right)$ and $75 \%\left(\mathrm{D}_{75 \%}\right)$ of the population was distributed. For species number see Table 1. The four species with solid circles (no. 9, 5, 12, 10) indicate suspension feeders in diapause in the deep layer (cf. Miller et al., 1984; Miller and Clemons, 1988). Note that the vertical (depth) scales are not the same among panels.

Fig. 6. Vertical distribution of detritivorous (a) and carnivorous (b) copepods at Station Knot in the western subarctic Pacific Ocean. Symbols indicate 50\% distribution depth $\left(\mathrm{D}_{50 \%}\right)$, and vertical bars indicate depth ranges where $25 \%\left(\mathrm{D}_{25 \%}\right)$ and $75 \%\left(\mathrm{D}_{75 \%}\right)$ of the population was distributed. For species number see Table 1 . Note that the vertical (depth) scales are not the same among panels.

Fig. 7. Vertical distribution of the number of genera and species of calanoid copepods at Station Knot in the western subarctic Pacific Ocean (left), species diversity indices ( $\left.H^{\prime}\right)$ based on their abundance and biomass data (middle), and similarity indices clustered by Mountford's method (right).

Fig. 8. Percentage composition of four feeding types of copepods in terms of their abundance (a) and biomass (b) at Station Knot in the western subarctic Pacific Ocean.

Fig. 9. Schematic diagram showing particulate carbon flux $\left(\mathrm{mg} \mathrm{C} \mathrm{m}^{-2} \mathrm{day}^{-1}\right)$ in the $0-4000$ $\mathrm{m}$ water column via eight depth strata in the western subarctic Pacific Ocean. Copepod ingestion and egestion rates were shown as mean values of day and night, and estimated from the formulas of Ikeda and Motoda (1978) and Ikeda et al. (2001). Primary production (PP) was measured directly, and downward flux was estimated by the formula of Suess (1980).

Fig. 10. Percentage composition of copepod carcasses separated into the three orders (Calanoida, Cyclopoida and Poecilostomatoida) and expressed by abundance (a) and biomass (b) at Station Knot in the western subarctic Pacific Ocean. Note that carcasses of Harpacticoida did not occur. 
Table 1

List of species of calanoid copepods at Station Knot in the western subarctic Pacific

\begin{tabular}{|c|c|c|c|}
\hline No. & Species & inds $\mathrm{m}^{-2}$ & $\mathrm{mgCm}{ }^{-2}$ \\
\hline \multicolumn{4}{|c|}{ Suspension feeders } \\
\hline 1 & Cyclopoida & 391727 & 1569.7 \\
\hline 2 & Microcalanus pygmaeus & 13351 & 39.6 \\
\hline 3 & Metridia pacifica & 11452 & 334.5 \\
\hline 4 & Paracalanus parvus & 11267 & 90.2 \\
\hline 5 & Eucalanus bungiti & 7566 & 2302.4 \\
\hline 6 & Harpacticoida & 5556 & 58.2 \\
\hline 7 & Pseudocalanus minutus & 3648 & 15.8 \\
\hline 8 & Calanus pacificus & 3353 & 62.1 \\
\hline 9 & Neocalanus cristatus $^{a}$ & 3082 & 1296.4 \\
\hline 10 & Neocalanus fleminger $i^{a}$ & 2896 & 679.3 \\
\hline 11 & Metridia Okhotensis & 2233 & 313.4 \\
\hline 12 & Neocalanus plumchrus ${ }^{a}$ & 2220 & 390.3 \\
\hline 13 & Gaidius variabilis & 2093 & 45.1 \\
\hline 14 & Pleuromamma scutullata & 1275 & 51.1 \\
\hline 15 & Gaetanus simplex & 1270 & 29.2 \\
\hline 16 & Metrida asymmetrica & 1245 & 109.1 \\
\hline 17 & Spinocalanus spinipes & 1057 & 31.8 \\
\hline 18 & Pseudocalanus newmani & 1003 & 4.1 \\
\hline 19 & Lucicutia flavicornis & 783 & 13.4 \\
\hline 20 & Lucicutia ovaliformis & 716 & 11.3 \\
\hline 21 & Metridia curticauda & 195 & 14.2 \\
\hline 22 & Spinocalanus similis & 185 & 2.1 \\
\hline 23 & Lucicutia ellipsoidalis & 156 & 6.7 \\
\hline 24 & Lucicutia frigida & 118 & 2.0 \\
\hline 25 & Acartia longiremis & 116 & 0.5 \\
\hline 26 & Metridia gurjanovae & 84 & 8.1 \\
\hline 27 & Gaidius brevispinus & 84 & 10.7 \\
\hline 28 & Aetideus pacificus & 68 & 1.7 \\
\hline 29 & Gaidius brevirostris & 48 & 6.3 \\
\hline 30 & Gaidius tenuispinus & 36 & 5.2 \\
\hline 31 & Gaetanus brevicornis & 34 & 5.7 \\
\hline 32 & Pseudochirella polyspina & 30 & 10.2 \\
\hline 33 & Mesocalanus tenuicornis & 29 & 0.2 \\
\hline 34 & Pseudochirella pacifica & 25 & 2.4 \\
\hline 35 & Rhincalanus nasutus & 25 & 6.6 \\
\hline 36 & Euchirella sp. & 25 & 0.2 \\
\hline 37 & Metridia similis & 23 & 0.9 \\
\hline 38 & Metridia ornata & 21 & 16.3 \\
\hline 39 & Spinocalanus magnus & 21 & 1.0 \\
\hline 40 & Euchirella rostrata & 19 & 1.3 \\
\hline 41 & Metridia brevicauda & 17 & 0.5 \\
\hline 41 & Undeuchaeta sp. & 17 & 2.5 \\
\hline 43 & Spinocalanus stellatus & 15 & 1.0 \\
\hline 44 & Lucicutia pacifica & 11 & 1.8 \\
\hline 45 & Metridia princeps & 11 & 7.8 \\
\hline 46 & Aetideopsis rostrata & 8 & 1.3 \\
\hline 47 & Pseudochirella spectabilis & 8 & 6.9 \\
\hline 48 & Gaetanus paracurvicornis & 4 & 0.8 \\
\hline 49 & Lucicutia gracilis & 4 & 3.3 \\
\hline 50 & Lucicutia longifurca & 4 & 1.6 \\
\hline 51 & Pseudochirella sp. & 4 & 0.9 \\
\hline 52 & Pseudochirella spinifera & 4 & 1.0 \\
\hline 53 & Gaetanus secundus & 2 & 0.3 \\
\hline 54 & Lucicutia grandis & 2 & 1.7 \\
\hline 55 & Lucicutia orientalis & 2 & 0.2 \\
\hline 56 & Undeuchaeta major & 2 & 0.5 \\
\hline
\end{tabular}

Table 1 (Continued)

\begin{tabular}{clrc}
\hline No. & Species & inds $^{-2}$ & $\mathrm{mg} \mathrm{C} \mathrm{m}^{-2}$ \\
\hline 57 & Undinopsis pacificus & 2 & 0.3 \\
58 & Lucicutia profunda & 1 & 0.1 \\
59 & Lucicutia oblonga & 1 & 0.1 \\
& & & \\
& & \\
Detritivores & 123063 & 542.4 \\
60 & Poecilostomatoida & 1039 & 11.9 \\
61 & Scolecithricella mintor & 985 & 33.8 \\
62 & Racovitzanus antarcticus & 729 & 19.7 \\
63 & Scaphocalantus subbrevicornis & 335 & 9.6 \\
64 & Scolecithricella ovata & 131 & 2.4 \\
65 & Scolecithricella globulosa & 126 & 26.5 \\
66 & Scaphocalanus magnus & 76 & 5.5 \\
67 & Scaphocalanus medius & 55 & 9.2 \\
68 & Amallothrix inornata & 42 & 1.8 \\
69 & Amallothrix sp. & 40 & 5.7 \\
70 & Amallothrix valida & 38 & 1.6 \\
71 & Amallothrix paravalida & 27 & 2.6 \\
72 & Xanthocalanus kurilensis & 25 & 0.7 \\
73 & Scaphocalanus insignis & 13 & 3.2 \\
74 & Scaphocalanus affinis & 8 & 3.3 \\
75 & Lophothrix frontalis & 4 & 1.1 \\
76 & Onchocalanus magnus & 4 & 1.0 \\
77 & Scottocalanus securifrons & &
\end{tabular}

\section{Carnivores}

\begin{tabular}{rlrr}
78 & Heterorhabdus tanneri & 864 & 67.3 \\
79 & Paraeuchaeta birostrata & 821 & 141.0 \\
80 & Paraeuchaeta elongata & 653 & 90.8 \\
81 & Paraeuchaeta rubra & 303 & 85.0 \\
82 & Heterostylites major & 204 & 28.6 \\
83 & Haloptilus pseudooxycephalus & 84 & 14.2 \\
84 & Heterorhabdus robustoides & 57 & 11.2 \\
85 & Heterorhabdus pacificus & 36 & 3.5 \\
86 & Candacia bipinnata & 31 & 0.9 \\
87 & Paraeuchaeta pseudotumidula & 28 & 5.0 \\
88 & Candacia columbiae & 25 & 3.8 \\
89 & Heterorhabdus compactus & 21 & 1.9 \\
90 & Euaugaptilus similis & 11 & 3.0 \\
91 & Euaugaptilus pseudaffinis & 8 & 1.3 \\
92 & Halptilus longicirrus & 8 & 1.4 \\
93 & Pachyptilus pacificus & 8 & 1.8 \\
94 & Augaptilus cormutus & 6 & 1.7 \\
95 & Paraeuchaeta barbata & 6 & 4.3 \\
96 & Euaugaptilus graciloides & 5 & 1.4 \\
97 & Euaugaptilus parabullifer & 4 & 1.7 \\
98 & Paraeuchaeta abyssalis & 4 & 4.6 \\
99 & Paraeuchaeta brevirostris & 4 & 0.8 \\
100 & Neoaugaptilus distinctus & 2 & 1.2 \\
101 & Paraeuchaeta orientallis & 1 & 0.5 \\
\hline & & & \\
\hline & & &
\end{tabular}

Abundance (individuals $\mathrm{m}^{-2}: \quad 0-4000 \mathrm{~m}$ ) and biomass $\left(\mathrm{mg} \mathrm{C} \mathrm{m}^{-2}: 0-4000 \mathrm{~m}\right)$ of each species and that of cyclopoida, Harpacticoida and Poecilostomatoida are also shown (values were mean of day and night). Based on the feeding pattern, copepods divided into four types: suspension feeders, suspension feeders in diapause, detritivores and carnivores.

a Indicate suspension feeders in diapause (cf. Miller et al., 1984; Miller and Clemons, 1988). 
Table 2

Regression statistics of abundance/biomass of copepods on depth

\begin{tabular}{llllr}
\hline Exponential model & $a$ & $b$ & $r^{2}$ & \multicolumn{1}{l}{$p$} \\
\hline Abundance (day) & 5.81 & $-7.27 \times 10^{-4}$ & 0.81 & 0.0024 \\
Abundance (night) & 5.65 & $-7.49 \times 10^{-4}$ & 0.77 & 0.0040 \\
Biomass (day) & 3.99 & $-7.27 \times 10^{-4}$ & 0.99 & $<0.0001$ \\
Biomass (night) & 4.13 & $-7.79 \times 10^{-4}$ & 0.89 & 0.0003 \\
\hline Power model & $a^{\prime}$ & $b^{\prime}$ & $r^{2}$ & \multicolumn{1}{c}{$p$} \\
\hline Abundance (day) & 9.17 & -1.52 & 0.96 & $<0.0001$ \\
Abundance (night) & 8.65 & -1.41 & 0.74 & 0.0064 \\
Biomass (day) & 6.22 & -1.10 & 0.72 & 0.0081 \\
Biomass (night) & 6.81 & -1.32 & 0.64 & 0.0167 \\
\hline
\end{tabular}

Regression models are exponential $\left(\log _{10} Y=a+b X\right)$ and power $\left(\log _{10} Y=a^{\prime}+b^{\prime} \log _{10} X\right)$ ones, where $Y$ is abundance (individuals $1000 \mathrm{~m}^{-3}$ ) or biomass $\left(\mu \mathrm{g} \mathrm{C} \mathrm{m}{ }^{-3}\right), X$ is depth in $\mathrm{m}$, and $a, b, a^{\prime}$ and $b^{\prime}$ are fixed constants.

Table 3

Ingestion rates $\left(\mathrm{mg} \mathrm{C} \mathrm{m}^{-2} \mathrm{day}^{-1}\right)$ of detritivorous copepods as compared with biomass of copepod carcasses $\left(\mathrm{mg} \mathrm{C}^{-2}\right)$ at each depth stratum in the western subarctic Pacific

\begin{tabular}{|c|c|c|c|c|c|c|}
\hline \multirow{2}{*}{$\begin{array}{l}\text { Depth } \\
\text { stratum (m) }\end{array}$} & \multicolumn{3}{|l|}{ Day } & \multicolumn{3}{|l|}{ Night } \\
\hline & $\begin{array}{l}\text { Ingestion rates, } A \\
\left(\mathrm{mg} \mathrm{Cm}^{-2} \mathrm{day}^{-1}\right)\end{array}$ & $\begin{array}{l}\text { Carcass biomass, } B \\
\left(\mathrm{mgC} \mathrm{m}^{-2}\right)\end{array}$ & $B / A$ & $\begin{array}{l}\text { Ingestion rates, } A \\
\left(\mathrm{mg} \mathrm{C} \mathrm{m}^{-2} \mathrm{day}^{-1}\right)\end{array}$ & $\begin{array}{l}\text { Carcass biomass, } B \\
\left(\mathrm{mg} \mathrm{C} \mathrm{m}^{-2}\right)\end{array}$ & $B / A$ \\
\hline $0-100$ & 2.7 & 23.2 & 8.6 & 11.5 & 18.4 & 1.6 \\
\hline $100-200$ & 9.7 & 24.2 & 2.5 & 1.3 & 6.7 & 5.3 \\
\hline $200-500$ & 28.9 & 53.2 & 1.8 & 24.0 & 37.7 & 1.6 \\
\hline $1000-1500$ & 11.5 & 40.4 & 3.5 & 13.1 & 56.5 & 4.3 \\
\hline $1500-2000$ & 4.4 & 24.9 & 5.6 & 8.0 & 43.2 & 5.4 \\
\hline $2000-3000$ & 3.0 & 24.0 & 7.9 & 3.7 & 43.2 & 11.5 \\
\hline $3000-4000$ & 2.1 & 53.0 & 25.6 & 0.3 & 19.0 & 62.0 \\
\hline
\end{tabular}


Table 4

Comparison of vertical distribution pattern of copepods with their feeding patterns

\begin{tabular}{llll}
\hline \multicolumn{3}{c}{ Feeding pattern } & \\
\cline { 2 - 4 } & $\begin{array}{l}\text { Suspension } \\
\text { feeders (31) }\end{array}$ & $\begin{array}{l}\text { Detritivores } \\
(11)\end{array}$ & $\begin{array}{l}\text { Carnivores } \\
(13)\end{array}$ \\
\hline $\begin{array}{l}\text { Diel } \\
\text { difference }\end{array}$ & 47 & 241 & 110 \\
$(\mathrm{~m})$ & & & \\
$(\mathrm{sd})$ & 46 & 307 & 158 \\
\hline
\end{tabular}

"Diel difference" indicates diel variation in $D_{50 \%}$. Number in the parentheses is the number of species observed. (sd): standard deviation.

Table 5

Ingestion rates of carnivorous copepods $\left(\mathrm{mg} \mathrm{Cm}^{-2} \mathrm{day}^{-1}\right)$ as compared with potential prey biomass $\left(\mathrm{mg} \mathrm{Cm}^{-2}\right)$ at each depth stratum in the western subarctic Pacific

\begin{tabular}{|c|c|c|c|c|c|c|}
\hline \multirow{2}{*}{$\begin{array}{l}\text { Depth stratum } \\
(\mathrm{m})\end{array}$} & \multicolumn{3}{|l|}{ Day } & \multicolumn{3}{|l|}{ Night } \\
\hline & $\begin{array}{l}\text { Ingestion rates, } A \\
\left(\mathrm{mg} \mathrm{C} \mathrm{m}^{-2} \mathrm{day}^{-1}\right)\end{array}$ & $\begin{array}{l}\text { Prey biomass, } B \\
\left(\mathrm{mg} \mathrm{C} \mathrm{m}^{-2}\right)\end{array}$ & $B / A$ & $\begin{array}{l}\text { Ingestion rates, } A \\
\left(\mathrm{mg} \mathrm{Cm}^{-2} \mathrm{day}^{-1}\right)\end{array}$ & $\begin{array}{l}\text { Prey biomass, } B \\
\left(\mathrm{mg} \mathrm{C} \mathrm{m}^{-2}\right)\end{array}$ & $B / A$ \\
\hline $0-100$ & 0 & 740 & - & 3.49 & 1984 & 568 \\
\hline $100-200$ & 2.11 & 582 & 277 & 0.47 & 199 & 420 \\
\hline $200-500$ & 9.64 & 581 & 60 & 10.86 & 579 & 53 \\
\hline $500-1000$ & 9.50 & 469 & 49 & 8.55 & 478 & 56 \\
\hline $1000-1500$ & 2.86 & 190 & 66 & 4.14 & 267 & 64 \\
\hline $1500-2000$ & 0.93 & 85 & 92 & 2.98 & 148 & 50 \\
\hline $2000-3000$ & 1.46 & 96 & 65 & 2.15 & 118 & 55 \\
\hline $3000-4000$ & 0.07 & 49 & 688 & 0.09 & 11 & 118 \\
\hline
\end{tabular}

As potential prey, suspension feeding (excepting suspension feeders in diapause) and detritivorous copepods were assumed. 


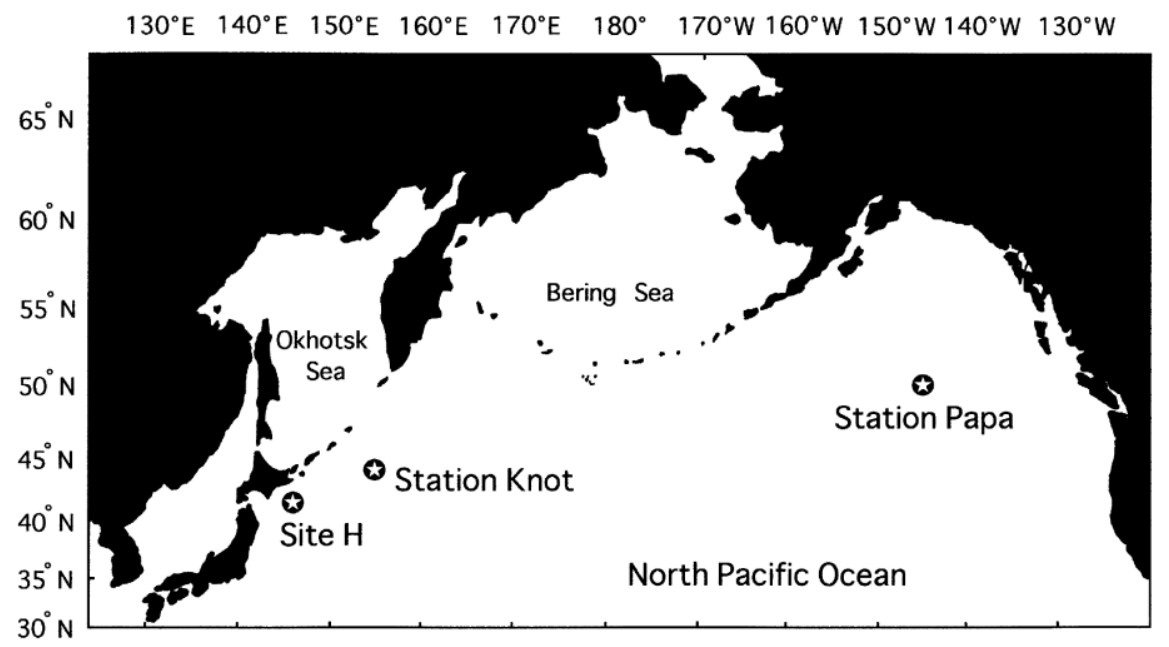

Fig. 1. Location of Station Knot $\left(44^{\circ} \mathrm{N}, 155^{\circ} \mathrm{E}\right)$ in the western subarctic Pacific Ocean. For comparison, locations of Station Papa (cf. Miller et al., 1984) in the eastern subarctic Pacific and Site H (cf. Kobari and Ikeda, 1999) in the western subarctic Pacific are superimposed.

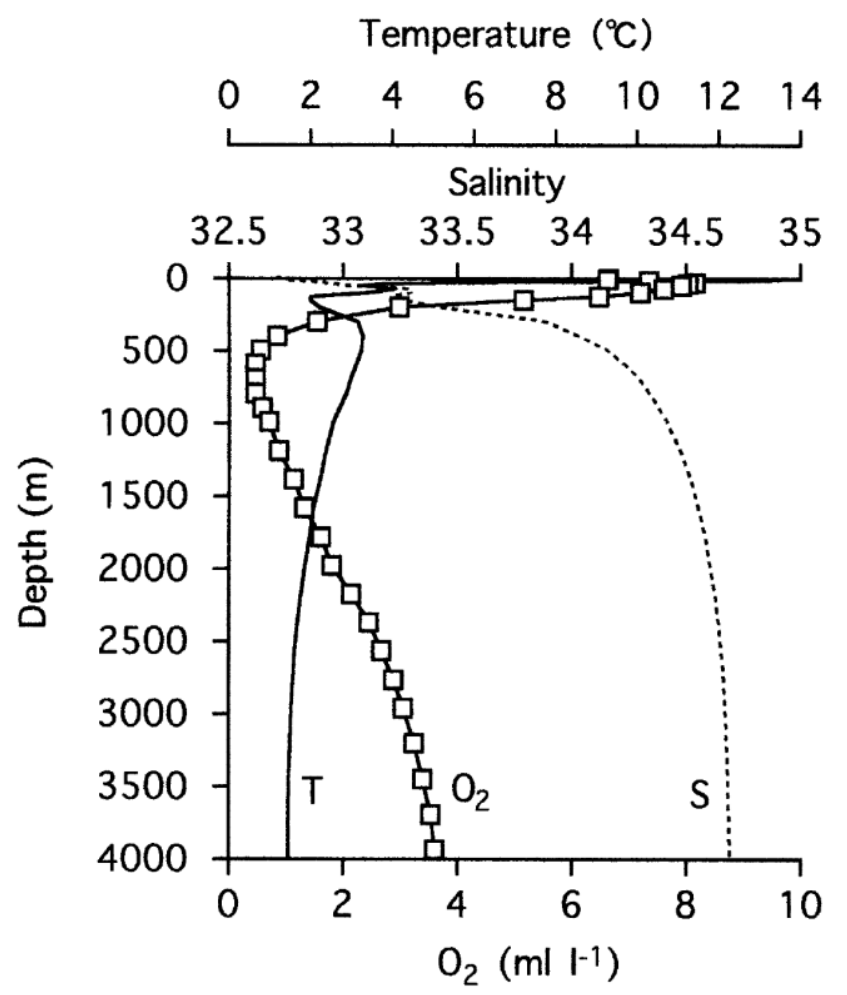

Fig. 2. Vertical distributions of temperature $\left({ }^{\circ} \mathrm{C}\right)$, salinity and dissolved oxygen $\left(\mathrm{mll}^{-1}\right)$ at Station Knot in the western subarctic Pacific Ocean, 19-21 August 1998. 

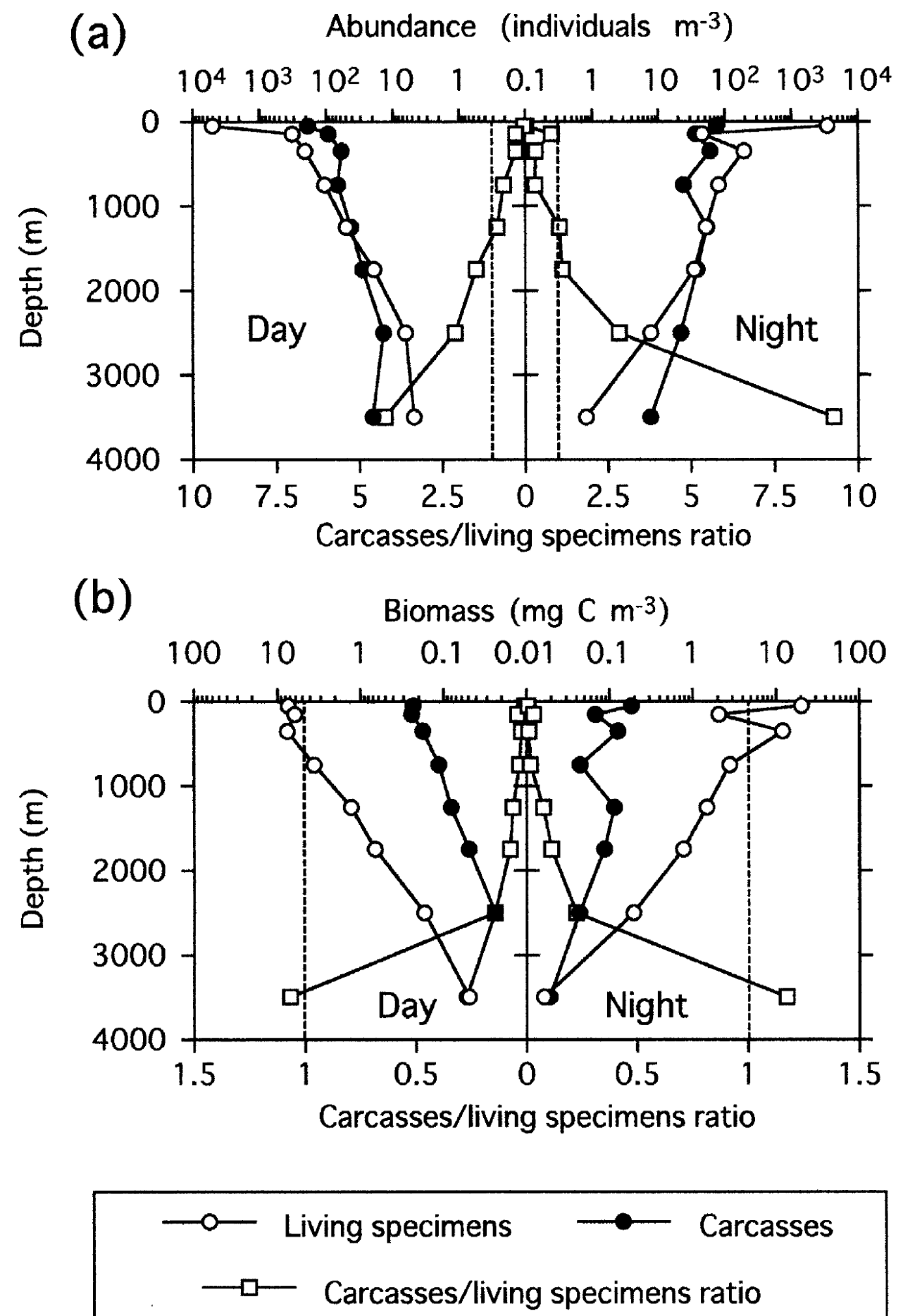

Fig. 3. Vertical distributions, on log scales, of abundance (a) and biomass (b) of copepods at Station Knot in the western subarctic Pacific Ocean. Squares denote ratio of carcasses to living specimens, and 1.0 values (carcasses equal to living specimens) are shown (dotted vertical lines). 

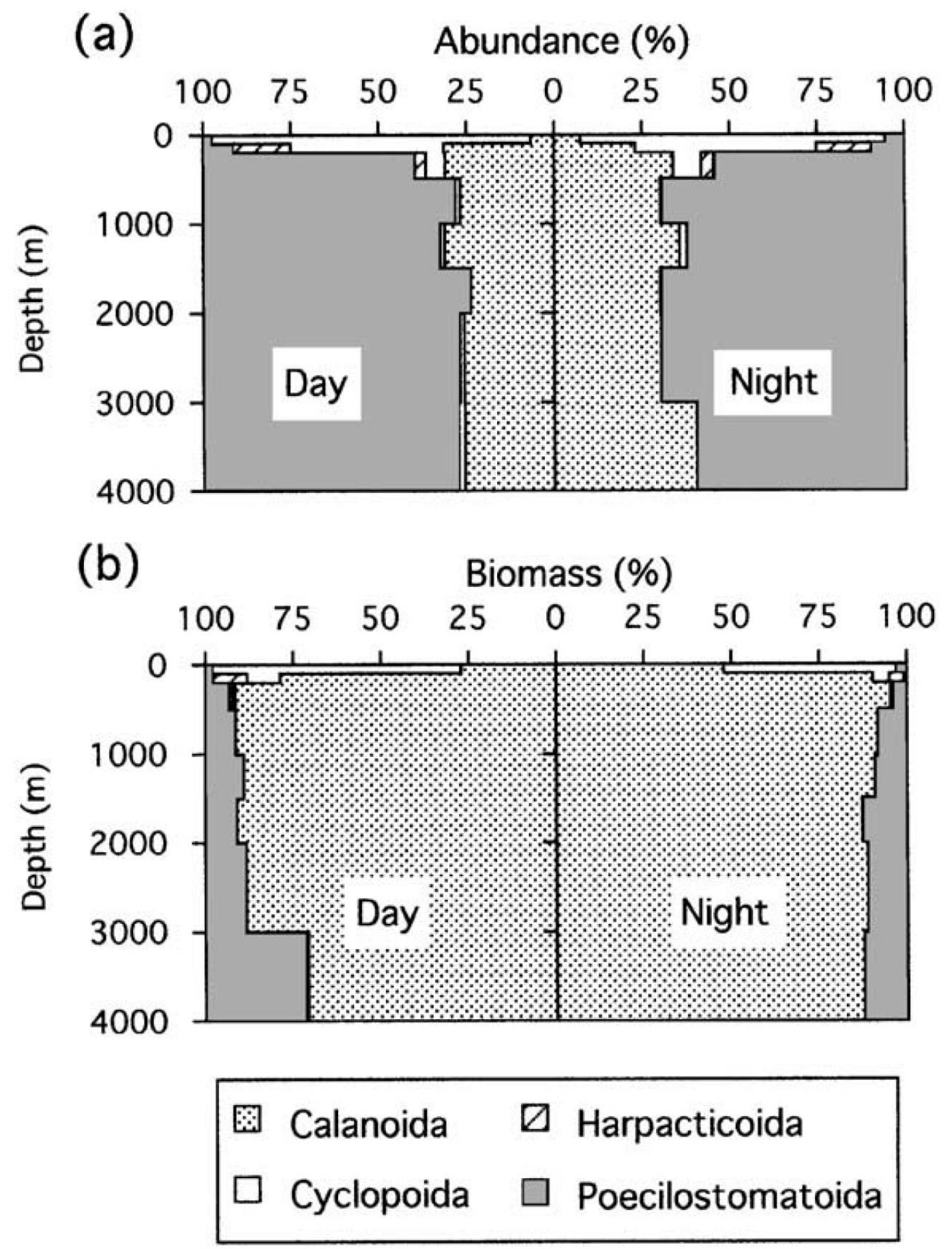

Fig. 4. Vertical changes in the composition of four orders (Calanoida, Cyclopoida, Harpacticoida and Poecilostomatoida) of copepods at Station Knot in the western subarctic Pacific Ocean in terms of abundance (a) and biomass (b). 


\section{Suspension feeders}

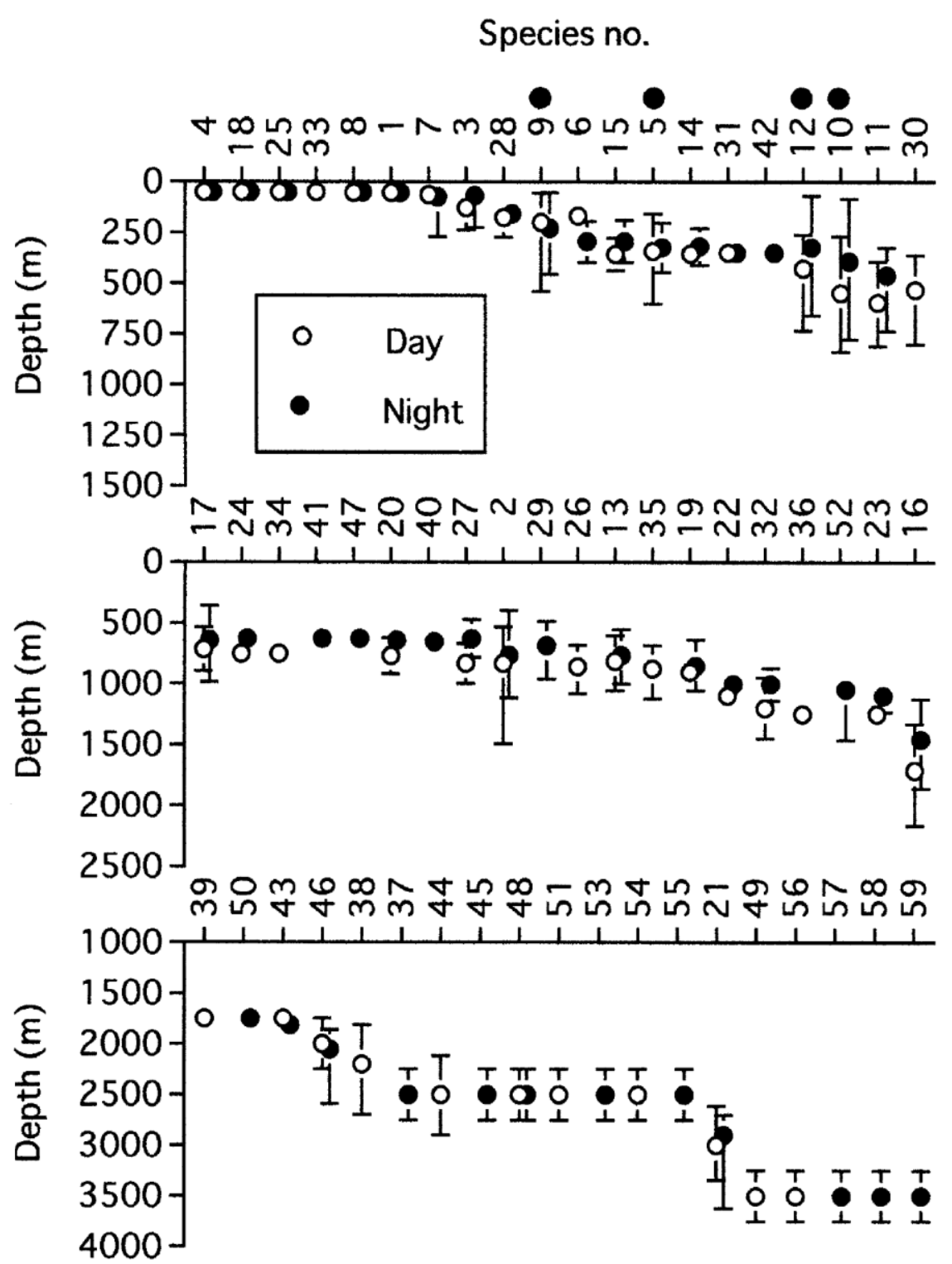

Fig. 5. Vertical distribution of suspension feeding copepods at Station Knot in the western subarctic Pacific Ocean. Of each species, open and solid symbols indicate $50 \%$ distribution depth $\left(D_{50 \%}\right)$ at day and night, respectively. Vertical bars indicate depth ranges where $25 \%\left(D_{25 \%}\right)$ and $75 \%\left(D_{75 \%}\right)$ of the population was distributed. For species number see Table 1. The four species with solid circles (no. 9, 5, 12, 10) indicate suspension feeders in diapause in the deep layer (cf. Miller et al., 1984; Miller and Clemons, 1988). Note that the vertical (depth) scales are not the same among panels. 


\section{(a) Detritivores}

Species no.

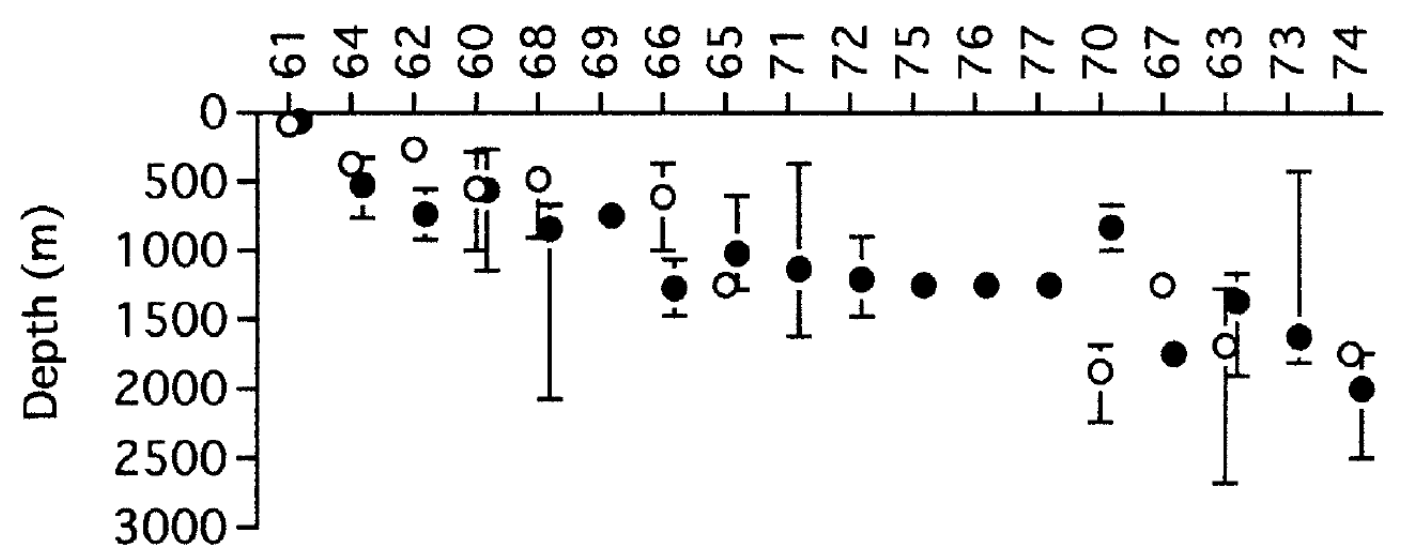

\section{(b) Carnivores}

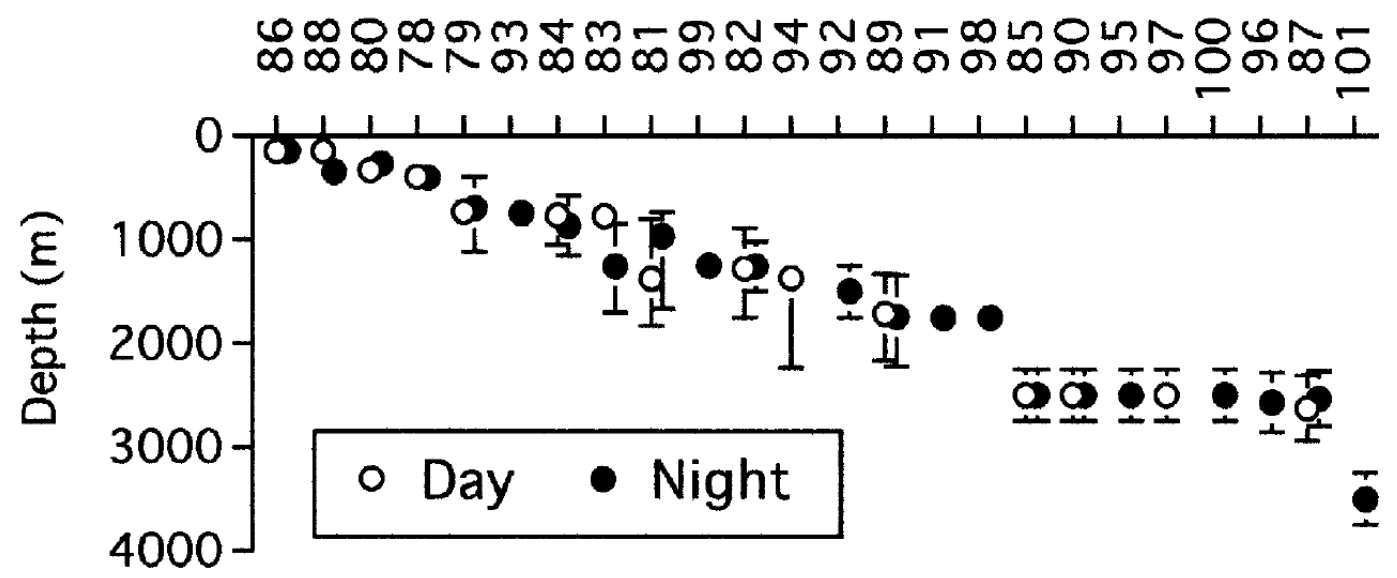

Fig. 6. Vertical distribution of detritivorous (a) and carnivorous (b) copepods at Station Knot in the western subarctic Pacific Ocean. Symbols indicate 50\% distribution depth $\left(D_{50 \%}\right)$, and vertical bars indicate depth ranges where $25 \%\left(D_{25 \%}\right)$ and $75 \%\left(D_{75 \%}\right)$ of the population was distributed. For species number see Table 1. Note that the vertical (depth) scales are not the same among panels. 


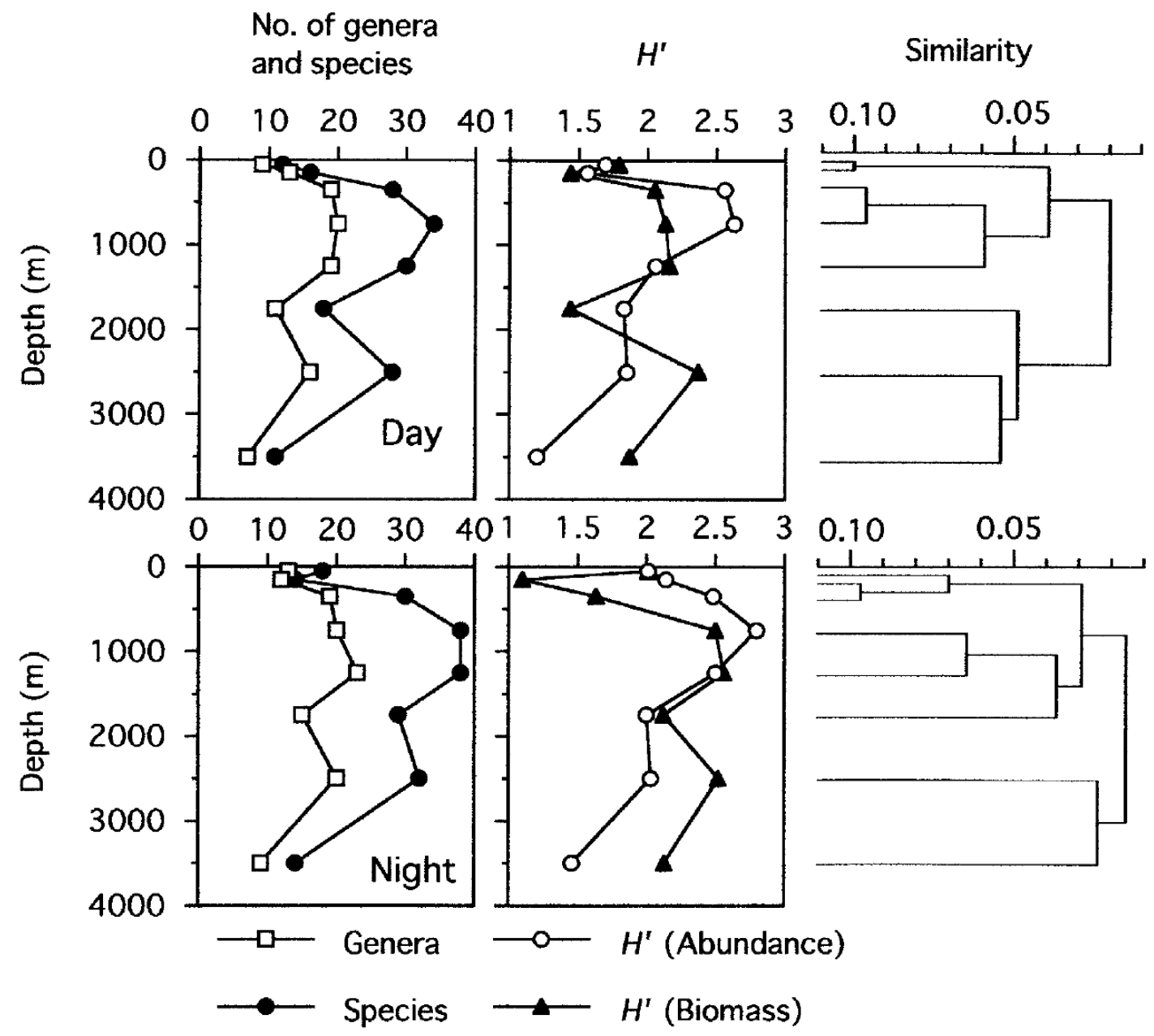

Fig. 7. Vertical distribution of the number of genera and species of calanoid copepods at Station Knot in the western subarctic Pacific Ocean (left), species diversity indices $\left(H^{\prime}\right)$ based on their abundance and biomass data (middle), and similarity indices clustered by Mountford's method (right). 

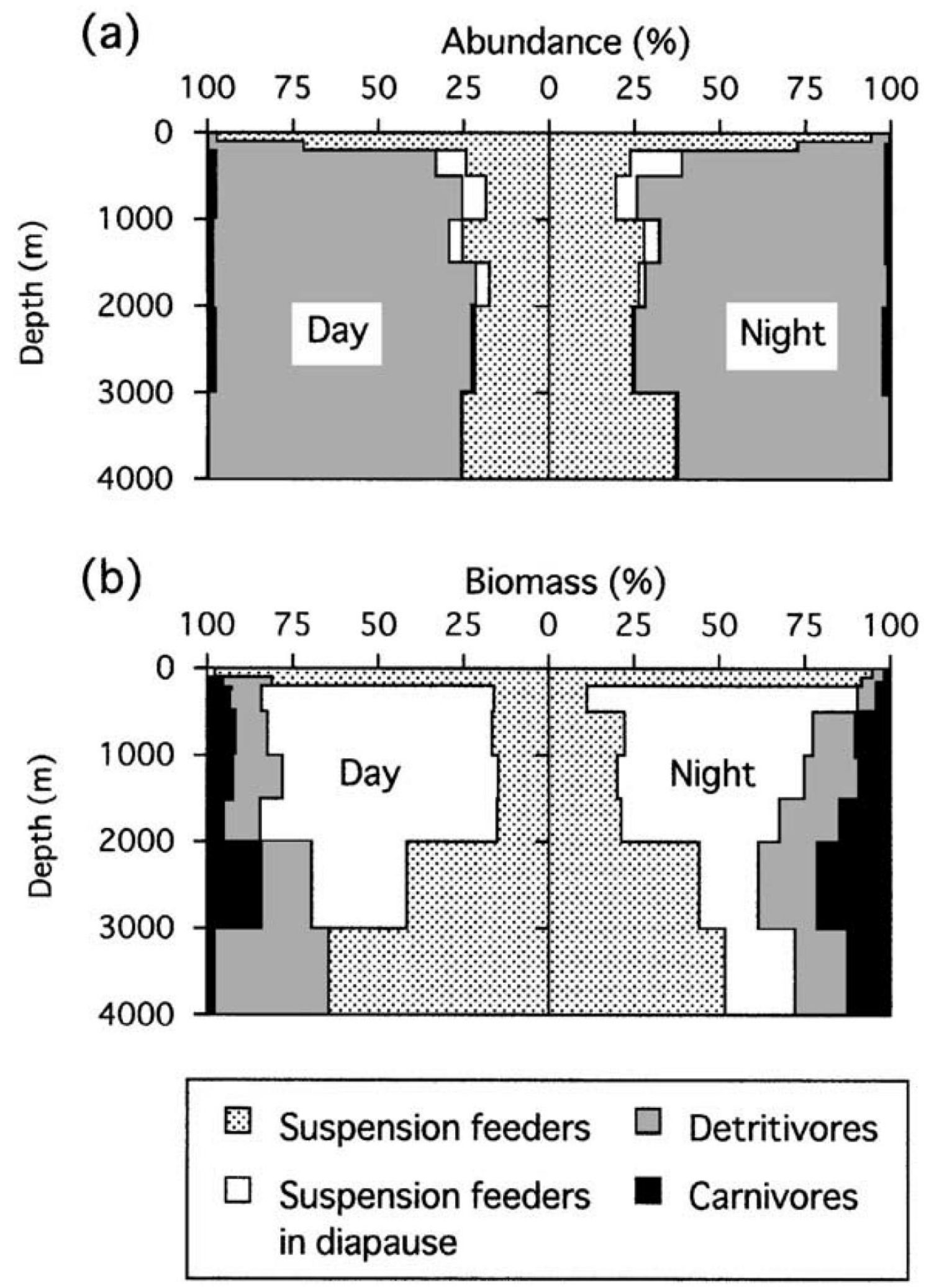

Fig. 8. Percentage composition of four feeding types of copepods in terms of their abundance (a) and biomass (b) at Station Knot in the western subarctic Pacific Ocean. 


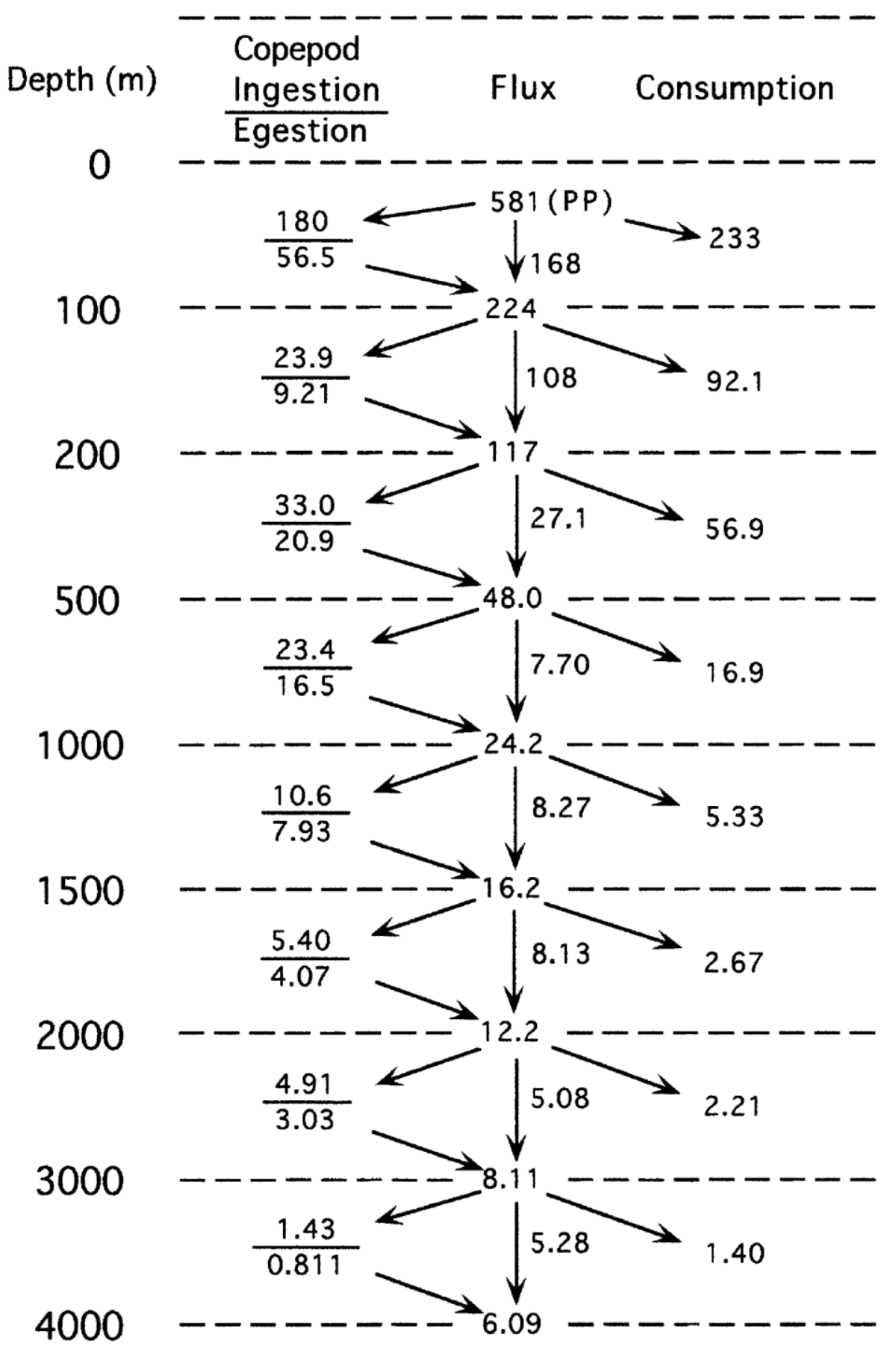

Fig. 9. Schematic diagram showing particulate carbon flux (mg $\mathrm{C} \mathrm{m}^{-2} \mathrm{day}^{-1}$ ) in the $0-4000 \mathrm{~m}$ water column via eight depth strata in the western subarctic Pacific Ocean. Copepod ingestion and egestion rates were shown as mean values of day and night, and estimated from the formulas of Ikeda and Motoda (1978) and Ikeda et al. (2001). Primary production (PP) was measured directly, and downward flux was estimated by the formula of Suess (1980). 


\section{(a) Copepod carcasses}
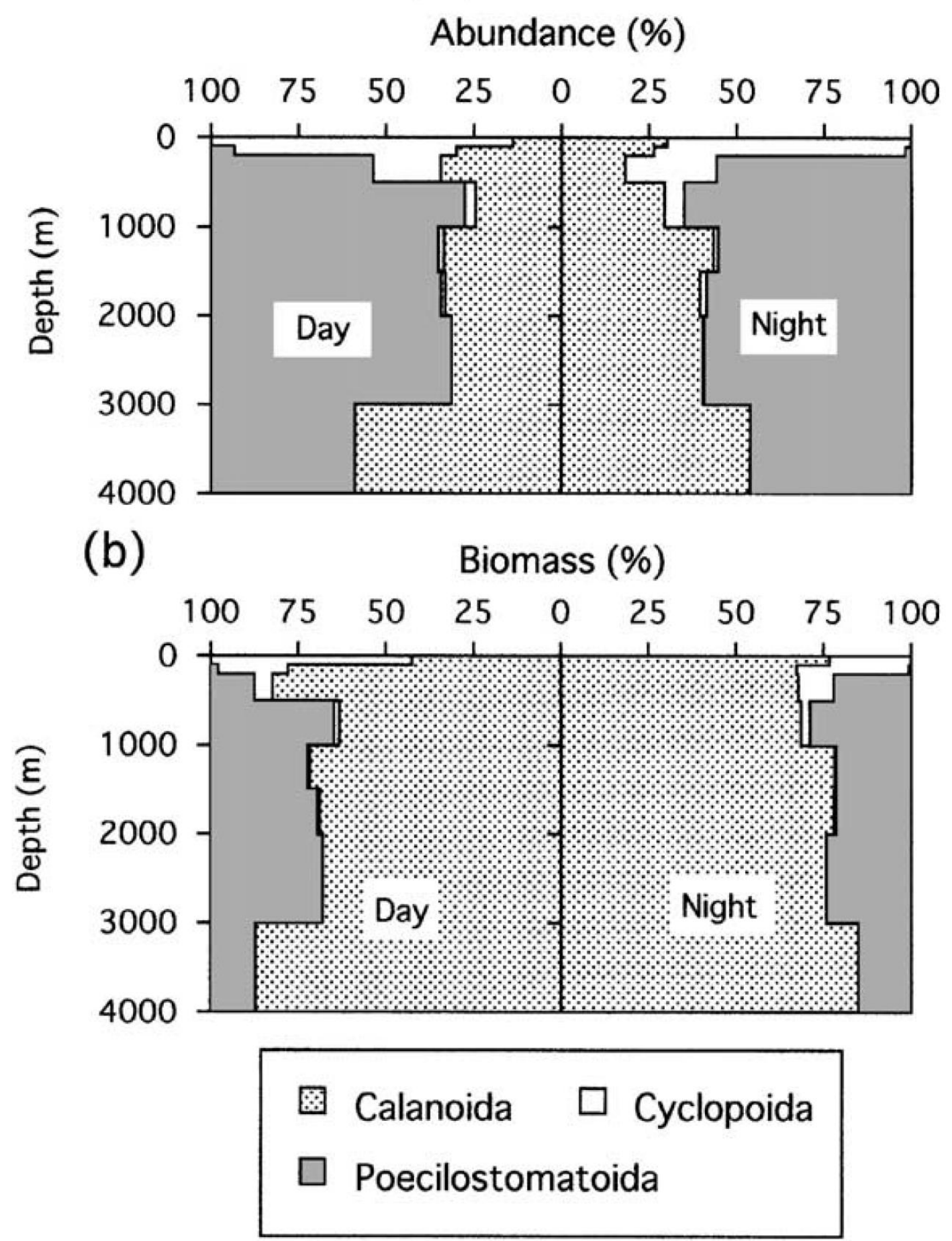

Fig. 10. Percentage composition of copepod carcasses separated into the three orders (Calanoida, Cyclopoida and Poecilostomatoida) and expressed by abundance (a) and biomass (b) at Station Knot in the western subarctic Pacific Ocean. Note that carcasses of Harpacticoida did not occur. 